\title{
Testing different decoupling coefficients with measurements and models of contrasting canopies and soil water conditions
}

\author{
V. Goldberg and C. Bernhofer \\ Technische Universität Dresden, Inst. for Hydrology and Meteorology, Dept. of Meteorology, 01062 Dresden, Germany
}

Received: 27 August 2007 - Revised: 16 June 2008 - Accepted: 23 June 2008 - Published: 22 July 2008

\begin{abstract}
Four different approaches for the calculation of the well established decoupling coefficient $\Omega$ are compared using measurements at three experimental sites (Tharandt spruce forest, Grillenburg and Melpitz - grass) and simulations from the soil-vegetation boundary layer model HIRVAC. These investigations aimed to quantify differences between the calculation routines regarding their ability to describe the vegetation-atmosphere coupling of grass and forest with and without water stress.

The model HIRVAC used is a vertically highly resolved atmospheric boundary layer model, which includes vegetation. It is coupled with a single-leaf gas exchange model to simulate physiologically based reactions of different vegetation types to changing atmospheric conditions. A multilayer soil water module and a functional parameterisation are the base in order to link the stomata reaction of the gas exchange model to the change of soil water.
\end{abstract}

The omega factor was calculated for the basic formulation according to McNaughton and Jarvis (1983) and three modifications. To compare measurements and simulations for the above mentioned spruce and grass sites, the summer period 2007 as well as a dry period in June 2000 were used. Additionally a developing water stress situation for three forest canopies (spruce, pine and beech) and for a grass site was simulated. The results showed large differences between the different omega approaches which depend on the vegetation type and the soil moisture.

Between the omega values, which were calculated by the used approach, the ranking was always the same not only for the measurements but also for the adapted simulations. The lowest values came from the first modification including doubling factors and summands in all parts of omega equation in relation to the original approach. And the highest values were calculated with the second modification missing

Correspondence to: V. Goldberg

(goldberg@forst.tu-dresden.de) one doubling factor in the denominator of the omega equation.

For example, the averages of omega ranged in the summer period 2007 from 0.11 to 0.19 for the spruce site and moderate soil wetness and from 0.42 to 0.58 for the grass site and higher soil wetness. In the case of the simulated drying out of four different canopies the forest stands showed a similar change of omega from about 0.65 (moderate soil wetness) to 0.1 (low soil wetness). The absolute change of omega for the grass canopy was smaller than for the forest canopies (on average from 0.95 to 0.7 ). But the differences between the used omega approaches increased.

Especially the results from the longer period in summer 2007 demonstrate that the various modifications of the decoupling coefficient lead to a change in the long-term quantity of omega. This has, for example, consequences for the description of the coupling of heterogeneous landscapes.

Keywords. Atmospheric composition and structure (Biosphere-atmosphere interactions) - Hydrology (Evapotranspiration)

\section{Introduction}

Three-dimensional land surface-atmosphere models like Large Eddy Simulation models (e.g. Shaw and Schumann, 1992; Watanabe, 2004) and meso-scale meteorological models (e.g. Steppeler et al., 2003) are more and more used to simulate physically based the interaction between heterogeneous landscapes and the atmosphere. Yet, due to their expensive demand on CPU time it is difficult to use this group of models for short-term case and sensitive studies. Hence, simple measures of the energetic and aerodynamic coupling between land surface and the atmosphere are used likewise to describe different kinds of landscape "heterogeneity" (Pinty et al., 1992).

Published by Copernicus Publications on behalf of the European Geosciences Union. 
For more than 20 years the decoupling coefficient omega $(\Omega)$ has been used as a basic measure to describe the partition between equilibrium and imposed evapotranspiration of a land surface (McNaughton and Jarvis, 1983) as well as to quantify the degree of the aerodynamic coupling between a vegetated surface and the atmospheric boundary layer (Jacobs and deBruin, 1992; Pinty et al., 1992; Goldberg and Bernhofer, 2001). After the fundamental work of McNaughton and Jarvis in 1983 various authors used the original omega approach for different applications (Meinzer and Grantz, 1989; Kelliher et al., 1990; Köstner et al., 1992; Herbst, 1995; Magnani et al., 1998; Mielke et al., 1999; Daamen and McNaughton, 2000; White et al., 2000; Wullschleger et al., 2000, 2002; Kumagai et al., 2004; Pereira, 2004; Motzer et al., 2005; Bladon et al., 2006). At the same time several modifications of the original equation were introduced using doubling factors and summands (Meinzer et al., 1993, 1997; Smith et al., 1998; Daudet et al., 1999; Martin et al., 2001) or including radiation feedback (Martin, 1989; McNaughton and Jarvis, 1991; Meinzer et al., 1993, 1997; Morris et al., 1998; Tausend et al., 2000), which is optionally combined with a structured vegetation (Pinty et al., 1992).

This results in a different aerodynamic coupling degree between the vegetation and the atmosphere, and the evaluation of the degree of transpiration control by the stomata (Martin, 1989). Not only the omega factor has a general importance to describe land surface characteristics, but also the majority of the authors could not clarify perfectly down which omega approach is the best for a special purpose. Due to these facts it remains necessary to estimate the significance of the deviations between the different calculation routines of the decoupling coefficient under extreme atmospheric and soil conditions.

In addition, most of the above mentioned authors found large differences of omega between rough (like forest) and smooth (like grass) land use types. Therefore, a standardised calculation of the coupling degree could be important for a simple classification of landscape "heterogeneity".

The present study aims to quantify the differences in the various modifications of the original approach of omega regarding their ability to describe the vegetation-atmosphere coupling of grass and forest sites with contrasting soil moisture conditions.

Measurements of a summer season, a comparison of measurements and simulations of a short-term summer period as well as the simulation of a dry period are analysed to summarise typical and extreme deviations between the different omega modifications. The results of this analysis are used to show the relevance of a pre-selected omega approach for the description of local and regional surface-atmosphere interactions.

\section{Methods}

2.1 Modifications for calculation of the decoupling coefficient $\Omega$

For the investigations in this study the following approaches for omega were used:

Original equation after McNaughton and Jarvis (1983):

$\Omega=\frac{\frac{s}{\gamma}+1}{\frac{s}{\gamma}+1+\frac{r_{c}}{r_{a}}}=\frac{\frac{s}{\gamma}+1}{\frac{s}{\gamma}+1+\frac{g_{a}}{g_{c}}}$

First modification after, e.g., Daudet et al. (1999):

$\Omega=\frac{\frac{s}{\gamma}+2}{\frac{s}{\gamma}+2+2 \frac{g_{b}}{g_{s}}}$

Second modification after, e.g., Smith et al. (1998):

$\Omega=\frac{\frac{s}{\gamma}+2}{\frac{s}{\gamma}+2+\frac{g_{b}}{g_{s}}}$,

and third modification after Martin (1989):

$\Omega=\frac{\varepsilon+1+\frac{g_{r}}{g_{b}}}{\varepsilon+\left(1+\frac{g_{b}}{g_{c}}\right)\left(1+\frac{g_{r}}{g_{b}}\right)}=\frac{\varepsilon+1+\frac{g_{r}}{g_{b}}}{\varepsilon+1+\frac{g_{b}}{g_{c}}+\frac{g_{r}}{g_{c}}+\frac{g_{r}}{g_{b}}}$

with

$g_{r}=\frac{\frac{4 \sigma T^{3} \Lambda}{c_{p}}}{\frac{p}{R T}}$

and $\sigma$ - Stefan-Boltzmann constant $\left(\mathrm{W} \mathrm{m}^{-2} \mathrm{~K}^{-4}\right), c_{p}-$ specific heat of dry air $\left(\mathrm{J} \mathrm{kg}^{-1} \mathrm{~K}^{-1}\right), g_{a}$ - aerodynamic conductance for sensible heat flux $\left(\mathrm{ms}^{-1}\right), g_{b}-$ aerodynamic boundary layer conductance of the canopy $\left(\mathrm{ms}^{-1}\right)$, $g_{c}$ - canopy conductance $\left(\mathrm{ms}^{-1}\right), g_{r}-$ longwave radiation transfer conductance of the canopy $\left(\mathrm{ms}^{-1}\right), \Lambda$ - leaf area index $\left(\mathrm{m}^{2} \mathrm{~m}^{-2}\right), p$ - air pressure $(\mathrm{Pa}), R$ - gas constant of dry air $\left(287 \mathrm{~J} \mathrm{~kg}^{-1} \mathrm{~K}^{-1}\right), r_{a}$ - aerodynamic resistance for sensible heat flux $\left(\mathrm{sm}^{-1}\right), r_{c}-$ canopy resistance $\left(\mathrm{sm}^{-1}\right), T-$ air temperature $(\mathrm{K}), \gamma$ $=p c_{p} /\left(L M_{v} / M_{\text {air }}\right)-$ psychrometric constant $\left(\mathrm{Pa} \mathrm{K}^{-1}\right)$, $L=2501000(T-273.15)-2370(T-273.15) \mathrm{J} \mathrm{kg}^{-1}-$ heat of vaporisation, $M_{v} / M_{\text {air }}=18.01 \mathrm{gmol}^{-1} / 28.96 \mathrm{gmol}^{-1}=0.622-$ relation between the molecular weights of water vapour and dry air, $s$ - slope of the saturation vapour pressure versus temperature $\left(\mathrm{Pa} \mathrm{K}^{-1}\right)$ and $\varepsilon=s / \gamma-$ dimensionless coefficient.

The first two modifications (Eqs. 2 and 3) differ from the original omega approach only in factors and summands of 2. These variations of the omega equation refer specifically to hypostomatous leaves, which have only stomata on their underside (as, e.g. most of trees (Smith and Jarvis, 1998)) whereas the original approach (Eq. 1) relates to amphistomatous leaves, having stomata on both sides of the leaf (as, e.g., grass (McNaughton and Jarvis, 1991)).

The third modification after Martin (1989) is a physically based extension of the basic approach after McNaughton and Jarvis (1983) including the effect of radiation cooling. 


\subsection{Soil vegetation boundary layer model HIRVAC}

HIRVAC (HIgh Resolution Vegetation Atmosphere Coupler) is a 1.5-dimensional boundary layer model (120 layers between 0 and $2 \mathrm{~km}$ ) including a highly resolved canopy (60 layers between 0 and $30 \mathrm{~m}$, Mix et al., 1994, Fig. 1). Vegetation is considered through additional terms in the model equations for momentum, temperature and humidity which are parameterised by the output (leaf boundary layer and stomata resistance) of a mechanistic photosynthesis module for $\mathrm{C}_{3}$ plants (PSN6, Falge et al., 1996, 2000; Goldberg and Bernhofer, 2001). Precipitation, interception, and soil moisture distribution are calculated by multi-layer models for interception and groundwater (Baums et al., 2005; Fischer et al., 2008).

The basic equations for momentum (Eqs. 6 and 7), temperature (Eq. 8), and humidity (Eq. 9) are already described in Goldberg and Bernhofer (2001):

$$
\begin{aligned}
& \frac{\partial v_{x}}{\partial t}=f\left(v_{y}-v_{g y}\right)+\frac{\partial}{\partial z} K \frac{\partial v_{x}}{\partial z}-j\left\{n_{w} c_{d} \operatorname{LAD} v_{x} \sqrt{\left(v_{x}^{2}+v_{y}^{2}\right)}\right\} \\
& \frac{\partial v_{y}}{\partial t}=-f\left(v_{x}-v_{g x}\right)+\frac{\partial}{\partial z} K \frac{\partial v_{y}}{\partial z}-j\left\{n_{w} c_{d} \operatorname{LAD} v_{y} \sqrt{\left(v_{x}^{2}+v_{y}^{2}\right)}\right\}(7) \\
& \frac{\partial \theta}{\partial t}=\frac{\partial}{\partial z} K_{T} \frac{\partial \theta}{\partial z}+\left(1-j n_{w}\right) \frac{1}{\rho c_{p}} \frac{\partial B_{l w}}{\partial z}+j\left\{\frac{\mathrm{LAD}}{r_{b}}\left(T_{W}-T\right)\right\} \\
& \frac{\partial q}{\partial t}=\frac{\partial}{\partial z} K_{q} \frac{\partial q}{\partial z}+j\left\{\frac{\mathrm{LAD}}{r_{b}+r_{s}}\left(q_{W}-q\right)\right\}
\end{aligned}
$$

with $z$ - vertical coordinate $(\mathrm{m}), v_{x}, v_{y}$ - components of horizontal wind speed $\left(\mathrm{ms}^{-1}\right), v_{g x}, v_{g y}$ - components of geostrophic wind speed $\left(\mathrm{ms}^{-1}\right), \Theta$ - potential temperature $(\mathrm{K}), K, K_{T}$, and $K_{q}$ - turbulent transfer coefficients for momentum, heat and moisture $\left(\mathrm{m}^{2} \mathrm{~s}^{-1}\right), f$ - coriolis parameter $\left(s^{-1}\right), B_{l w}-$ longwave atmospheric radiation $\left(\mathrm{W} \mathrm{m}^{-2}\right)$, $n_{w}=0 \ldots 1-$ crown cover, $c_{d}=0.1 \ldots 0.3-\mathrm{drag}$ coefficient, LAD - leaf area density $\left(\mathrm{m}^{2} \mathrm{~m}^{-2}\right), r_{b}, r_{s}$ - boundary layer and stomata resistance $\left(\mathrm{sm}^{-1}\right), T_{W}, T$ - temperature of the vegetation surface and the ambient air $(\mathrm{K}), q_{w}$ - specific saturation humidity at $T_{W}\left(\mathrm{~kg} \mathrm{~kg}^{-1}\right), q$ - specific humidity of the ambient air $\left(\mathrm{kg} \mathrm{kg}^{-1}\right)$, and $j=1$ inside, $j=0$ above the canopy.

This HIRVAC version was already applied and tested for experimental sites with different land uses and compared with several SVAT models (Falge et al., 2005).

In the new HIRVAC version the submodel PSN6 was modified by scaling several parameters with a power function of soil moisture (matrix potential $\psi$ ). This modification leads to a stomata reaction to a change in soil water content (Falge et al., 1997; Goldberg et al., 2005):

$$
\begin{aligned}
& g_{\mathrm{fac}}=g_{\mathrm{fac}, \mathrm{c}} 10^{1.294 \Psi-\Psi_{F C}} \\
& f_{v c}=f_{v c, c} 10^{1.294\left(\Psi-\Psi_{F C}\right)} \\
& c=c_{c} 10^{1.294\left(\Psi-\Psi_{F C}\right)}
\end{aligned}
$$

with $\Psi$ - actual matrix potential (MPa), $\Psi_{F C}-$ matrix potential in the effective root zone at field capacity (MPa), $g_{\text {fac }}$ - linear factor of the empirical model to describe stomata conductance in PSN6, $f_{v c}$ - carboxylase capacity, $c$ - electron transport capacity during photosynthesis process (Falge et al., 1996). The additional index " $c$ " refers to the constant input parameters before modification.

The negative sign of the matrix potential leads to a reduction of $g_{\text {fac }}, f_{v c}$ and $c$ in Eqs. (10) to (12) and, approached in the model PSN6, to a decrease of the stomata conductance (increase of stomata resistance, respectively). Therefore the effect of the additional humidity source term in Eq. (9) of HIRVAC is reduced. As a result the humidity profiles $(q=q(z))$ in the canopy air, the latent heat flux, and the energy balance of each canopy layer are modified.

\subsection{Calculation of omega using measured and simulated data}

The omega factor of this study was calculated using measured and simulated data for a complete canopy. Generally there are two different methods to determine the decoupling coefficient on canopy scale. The majority of the above mentioned authors used chamber measurements at leaf surface and scaled up afterwards to derive the omega factor for a stand (e.g. Daudet et al., 1999). During this scaling process leaf boundary layer $g_{b}$ and stomata conductance $g_{s}$ (Eqs. 2 to 4) are transferred to the aerodynamic and canopy conductance $g_{a}$ and $g_{c}$, respectively.

To determine the decoupling coefficient from micrometeorological measurements and simulations, $g_{a}$ and $g_{c}$ were calculated by an inversion of bulk approaches for sensible and latent heat flux, respectively:

$$
\begin{aligned}
& g_{a}=\frac{\mathrm{H}}{\rho c_{p}\left(T_{0}-T_{r}\right)}=1 / r_{a} \\
& g_{c}=\frac{1}{\frac{\rho L\left(q_{s}\left(T_{0}\right)-q\right)}{\mathrm{LE}}-\frac{\rho c_{p}\left(T_{0}-T_{r}\right)}{\mathrm{H}}}=1 / r_{c}=1 /\left(r_{v}-r_{a}\right)
\end{aligned}
$$

with H, LE - sensible heat flux, latent heat flux between the active surface inside and a reference layer above the canopy $\left(\mathrm{W} \mathrm{m}^{-2}\right), \rho-$ air density $\left(\mathrm{kg} \mathrm{m}^{-3}\right), c_{p}, L-$ specific heat capacity of dry air, heat of vaporisation $\left(\mathrm{J} \mathrm{kg}^{-1} \mathrm{~K}^{-1}\right), T_{0}$ - temperature of the active surface $(\mathrm{K}), q_{s}\left(T_{0}\right)$ - specific saturation humidity of the active surface $\left(\mathrm{kg} \mathrm{kg}^{-1}\right), T_{r}$ - temperature of the corresponding reference layer above the canopy $(\mathrm{K})$, $q$ - specific humidity of the corresponding reference layer above the canopy $\left(\mathrm{kg} \mathrm{kg}^{-1}\right), r_{v}$ - resistance of evapotranspiration, $r_{c}$ - canopy resistance, and $r_{a}$ - aerodynamic resistance $\left(\mathrm{sm}^{-1}\right)$.

The long wave radiation transfer conductance of the canopy is calculated by Eq. (5).

To have comparable results the LE in this study was calculated using results of the gas exchange model PSN6 (transpiration, scaled up to canopy level). The sensible heat 

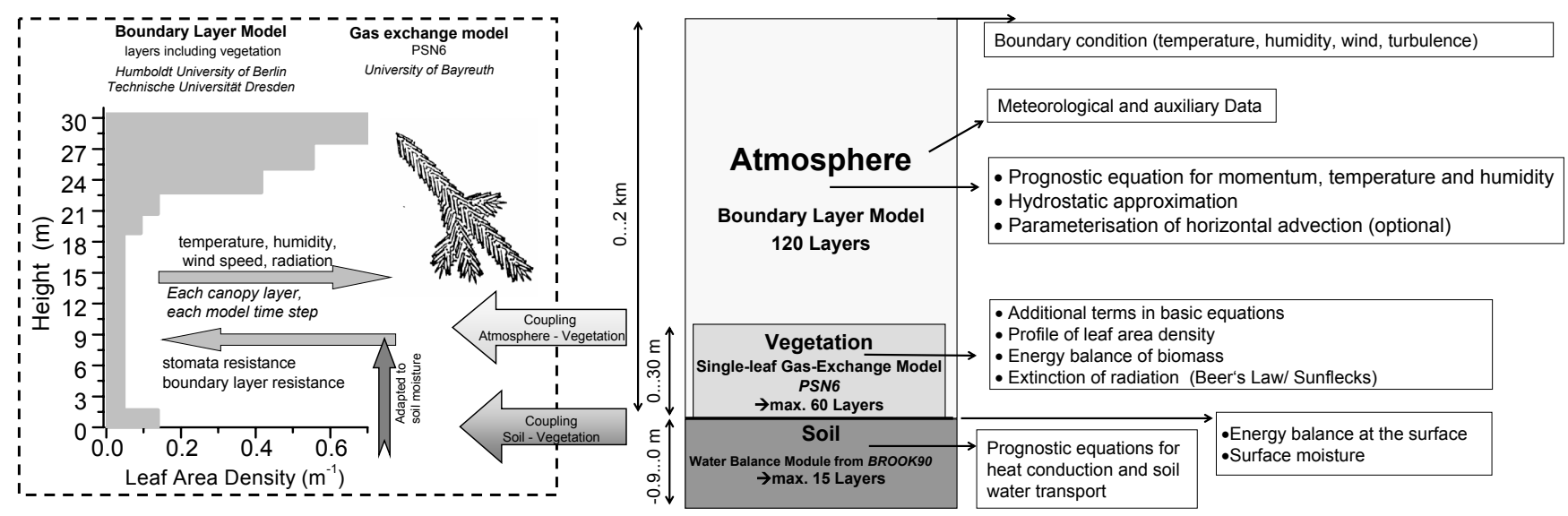

Fig. 1. Scheme of the HIgh Resolution Vegetation Atmosphere Coupler (HIRVAC).

Table 1. List of sensors and instruments used for the relevant measurements at the different sites.

\begin{tabular}{|c|c|c|c|c|}
\hline Quantity & Site & Name of the instrument & Type of the sensor/instrument & Company \\
\hline Temperature/Humidity & $\begin{array}{l}\text { Tharandt, Melpitz } \\
\text { Grillenburg }\end{array}$ & $\begin{array}{l}\text { HMP35 } \\
\text { HMP45A/C }\end{array}$ & Thermistor/Capacitive sensor & Vaisala \\
\hline Short wave radiation & $\begin{array}{l}\text { Melpitz } \\
\text { Tharandt } \\
\text { Grillenburg }\end{array}$ & $\begin{array}{l}\text { CM7 } \\
\text { CM7 } \\
\text { CM3 (CNR1) }\end{array}$ & $\begin{array}{l}\text { Pyranometer } \\
\text { Pyranometer } \\
\text { Pyranometer }\end{array}$ & Kipp \& Zonen \\
\hline Long wave radiation & $\begin{array}{l}\text { Tharandt, Melpitz } \\
\text { Grillenburg }\end{array}$ & $\begin{array}{l}\text { PIR } \\
\text { CG3 (CNR1) }\end{array}$ & $\begin{array}{l}\text { Pyrgeometer } \\
\text { Pyrgeometer }\end{array}$ & $\begin{array}{l}\text { Eppley } \\
\text { Kipp \& Zonen }\end{array}$ \\
\hline Net radiation & $\begin{array}{l}\text { Tharandt, Melpitz } \\
\text { Grillenburg }\end{array}$ & $\begin{array}{l}\text { CM7, PIR } \\
\text { CNR1 }\end{array}$ & $\begin{array}{l}\text { Combination of short wave } \\
\text { and long wave radiation sensors }\end{array}$ & $\begin{array}{l}\text { Kipp \& Zonen, Eppley } \\
\text { Kipp \& Zonen }\end{array}$ \\
\hline Soil moisture & $\begin{array}{l}\text { Tharandt } \\
\text { Grillenburg }\end{array}$ & $\begin{array}{l}\text { T6 } \\
\text { Trime-IT }\end{array}$ & $\begin{array}{l}\text { Tensiometer } \\
\text { TDR }\end{array}$ & $\begin{array}{l}\text { UMS/IMKO } \\
\text { IMKO }\end{array}$ \\
\hline
\end{tabular}

flux $(\mathrm{H})$ was generally calculated by flux-gradient relationship.

Measured data (half-hourly means) of the temperature and humidity gradients as well as of turbulent heat fluxes were used from three different sites - the Anchor Stations Tharandt, Grillenburg and Melpitz. The first site is a 113-yearold spruce stand (Picea abies) in the forest Tharandter Wald, $20 \mathrm{~km}$ southwest of Dresden (Saxony, Germany). The mean vegetation height rises to $28 \mathrm{~m}$, the projected leaf area index reaches 6 , and the crown cover is $75 \%$. Measurements of temperature, radiation, and humidity above the stand (reference level) are situated at a height of $40 \mathrm{~m}$ and for the turbulent heat fluxes at $42 \mathrm{~m}$. The second and the third site are farmed grass sites at Grillenburg, $3 \mathrm{~km}$ southwest of the first site, and Melpitz, $50 \mathrm{~km}$ northeast of Leipzig (Saxony, Germany) which is managed by the Institute for Tropospheric Research in Leipzig. These sites are flat and show a fairly good fetch. The mean grass height is about $0.15 \mathrm{~m}$, and the common height for all relevant measurements is $2 \mathrm{~m}$.
Table 1 gives an overview of the sensors and devices used for continuous measurements of temperature, humidity, radiation and soil moisture at the different sites.

During the field campaign at the Melpitz site no continuous measurements of soil moisture were carried out. Episodic TDR measurements were used to derive matrix potential to initialise the HIRVAC model.

\section{Results and discussion}

3.1 Comparison of omega approaches for different land uses and soil moisture regimes using long-term measurements in summer 2007

To compare the different omega approaches for a longer period, measurements (half-hour means) of the Anchor Stations Tharandt (spruce) and Grillenburg (grass) between April and September 2007 were used. Because the incoming radiation 
Table 2. Mean values and standard deviation of the omega approaches according to Eqs. (1) to (4) and derived from measurements (half hour means) at the Anchor Station Grillenburg (grass) and Tharandt (spruce) during the summer season 2007. The data was filtered for solar radiation $>400 \mathrm{~W} \mathrm{~m}^{-2}$, high wind speed (friction velocity $u^{*}>0.4 \mathrm{~ms}^{-1}$ for grass and $u^{*}>0.8 \mathrm{~ms}^{-1}$ for spruce) as well as for moderate (soil water content $\mathrm{SWC}<30 \%$ for grass and $\mathrm{SWC}<10 \%$ for spruce) and wet soil conditions (SWC $>40 \%$ for grass and $\mathrm{SWC}>20 \%$ for spruce).

\begin{tabular}{ccc|cc}
\hline & \multicolumn{3}{c}{$\Omega($ Mean $+/-$ standard deviation $)$} \\
\hline \multirow{4}{*}{$\begin{array}{c}\text { Type of canopy } \\
\text { approach }\end{array}$} & \multicolumn{3}{c}{ Spruce } & \multicolumn{2}{c}{ Grass } \\
\cline { 2 - 5 } & moderate & wet & moderate & wet \\
\hline 1 & $0.15 \pm 0.10$ & $0.22 \pm 0.10$ & $0.40 \pm 0.10$ & $0.50 \pm 0.14$ \\
2 & $0.11 \pm 0.08$ & $0.16 \pm 0.09$ & $0.32 \pm 0.09$ & $0.42 \pm 0.13$ \\
3 & $0.19 \pm 0.11$ & $0.27 \pm 0.12$ & $0.47 \pm 0.11$ & $0.58 \pm 0.12$ \\
4 & $0.14 \pm 0.09$ & $0.20 \pm 0.10$ & $0.35 \pm 0.09$ & $0.46 \pm 0.13$ \\
\hline
\end{tabular}

and the wind speed acted as driving forces of the decoupling coefficient, their typical large variability led to a big "noise" of calculated omega values. To show the differences between the used omega approaches more clearly the primary meteorological data was filtered for high solar radiation $\left(>400 \mathrm{~W} \mathrm{~m}^{-2}\right)$ and high wind speed (friction velocity $u^{*}>0.4 \mathrm{~ms}^{-1}$ for grass and $u^{*}>0.8 \mathrm{~ms}^{-1}$ for spruce). Additionally the data was separated as well by moderate soil wetness (soil water content $\mathrm{SWC}<30 \%$ for grass and SWC $<10 \%$ for spruce) as for high soil wetness (SWC $>40 \%$ for grass and SWC $>20 \%$ for spruce).

Figures 2 to 4 show the variability of turbulent heat fluxes, conductance and omega factor at the spruce and grass site using box plots. Figure 2 (top panel) illustrates the structure of this graph type used for all following in this chapter: Min=minimum, Max=maximum, $\mathrm{SD}=$ standard deviation and $50 \%=$ median of the analysed data set.

The different land uses show distinct differences for sensible (H) and latent heat flux (LE) (Fig. 2), aerodynamic $\left(g_{a}\right)$ and canopy conductance ( $g_{c}$, Fig. $3 \mathrm{a}$ and $\mathrm{b}$ ), and notably for the decoupling coefficient (Fig. 4). Due to the small temperature and LAI differences between the two sites, the deviations of long wave heat transfer conductance $g_{r}$ (see Eq. 5) are marginal. The mean values of $g_{r}$ range between 8 and $11 \mathrm{mms}^{-1}$ (Fig. 3c) which is comparable to the results derived by Martin (1989).

The strongest reaction to a change in soil moisture shows the spruce canopy for $\mathrm{H}$ (decrease in case of wet soil, Fig. 2 above). At the grass site the change of both turbulent heat fluxes which depends on soil moisture is small (Fig. 2 below). This is exactly the same for LE at the spruce site. Caused by similar mean LE between the contrasting vegeta-

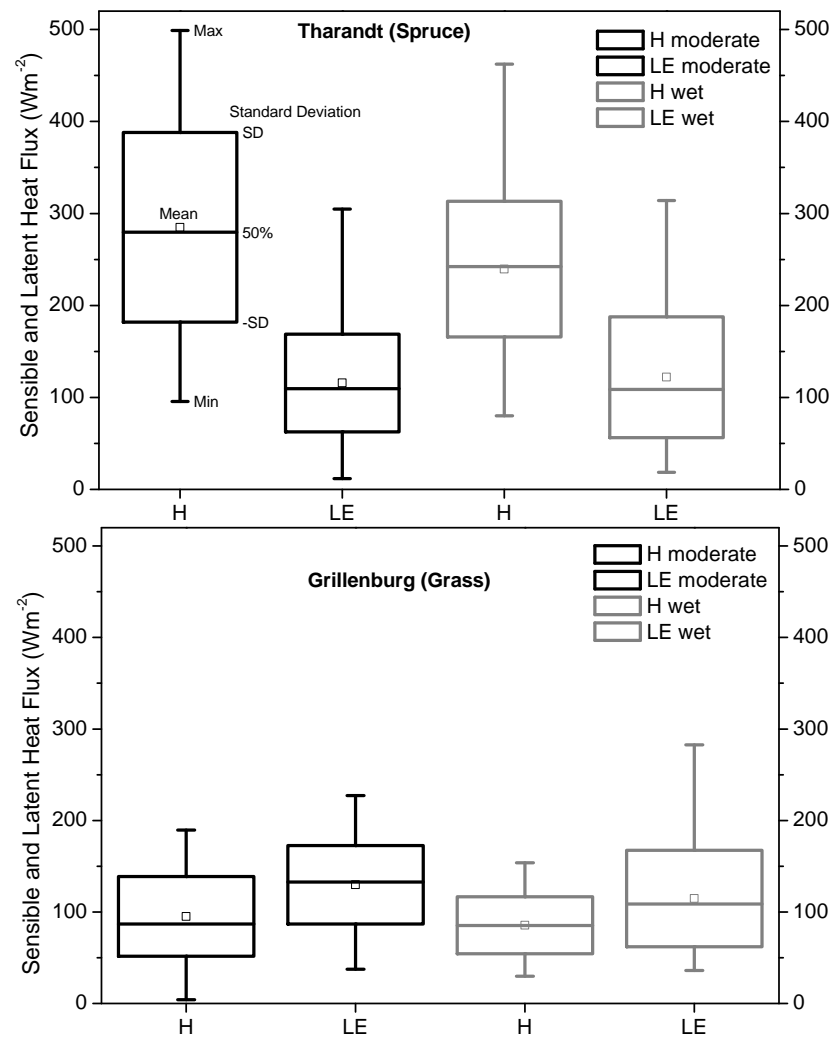

Fig. 2. Measurements (box plots of half hour means) of sensible (H) and latent heat fluxes (LE) at the Anchor Stations Tharandt (spruce, panel above) and Grillenburg (grass, panel below) during the summer season 2007. The data was filtered for solar radiation $>400 \mathrm{~W} / \mathrm{m}^{2}$, high wind speed (friction velocity $u^{*}>0.4 \mathrm{~m} / \mathrm{s}$ for grass and $u^{*}>0.8 \mathrm{~m} / \mathrm{s}$ for spruce), as well as for moderate (soil water content $\mathrm{SWC}<30 \%$ for grass and $\mathrm{SWC}<10 \%$ for spruce) and wet soil conditions (SWC $>40 \%$ for grass and SWC $>20 \%$ for spruce).

tion types, $g_{c}$ of the spruce site is just slightly higher (mean $g_{c}=7 \mathrm{mms}^{-1}$ for moderate and $8 \mathrm{mms}^{-1}$ for high soil wetness, Fig. 3a) than $g_{c}$ of the grass site. Yet, since the coupling with the atmosphere is better, $g_{a}$ is much greater for the forest site (about $80 \mathrm{mms}^{-1}$, in contrast to $20 \mathrm{mms}^{-1}$ for the grass site, Fig. 3b). Both $g_{c}$ and $g_{a}$ show much higher variation for the spruce site.

Figure 4 illustrates the differences between the four omega calculations for the two contrasting land uses. The results demonstrate that the ranking between the modifications is always the same. With the second modification (Eq. 3) in Sect. 2.1 the highest omega values are calculated. And the lowest values are determined with the first modification from the original approach (Eq. 2). For wet soil conditions the decoupling coefficient is in general higher - its average ranges between 0.58 and 0.42 for grass and between 0.27 and 0.16 for spruce. In the case of moderate soil conditions the values 


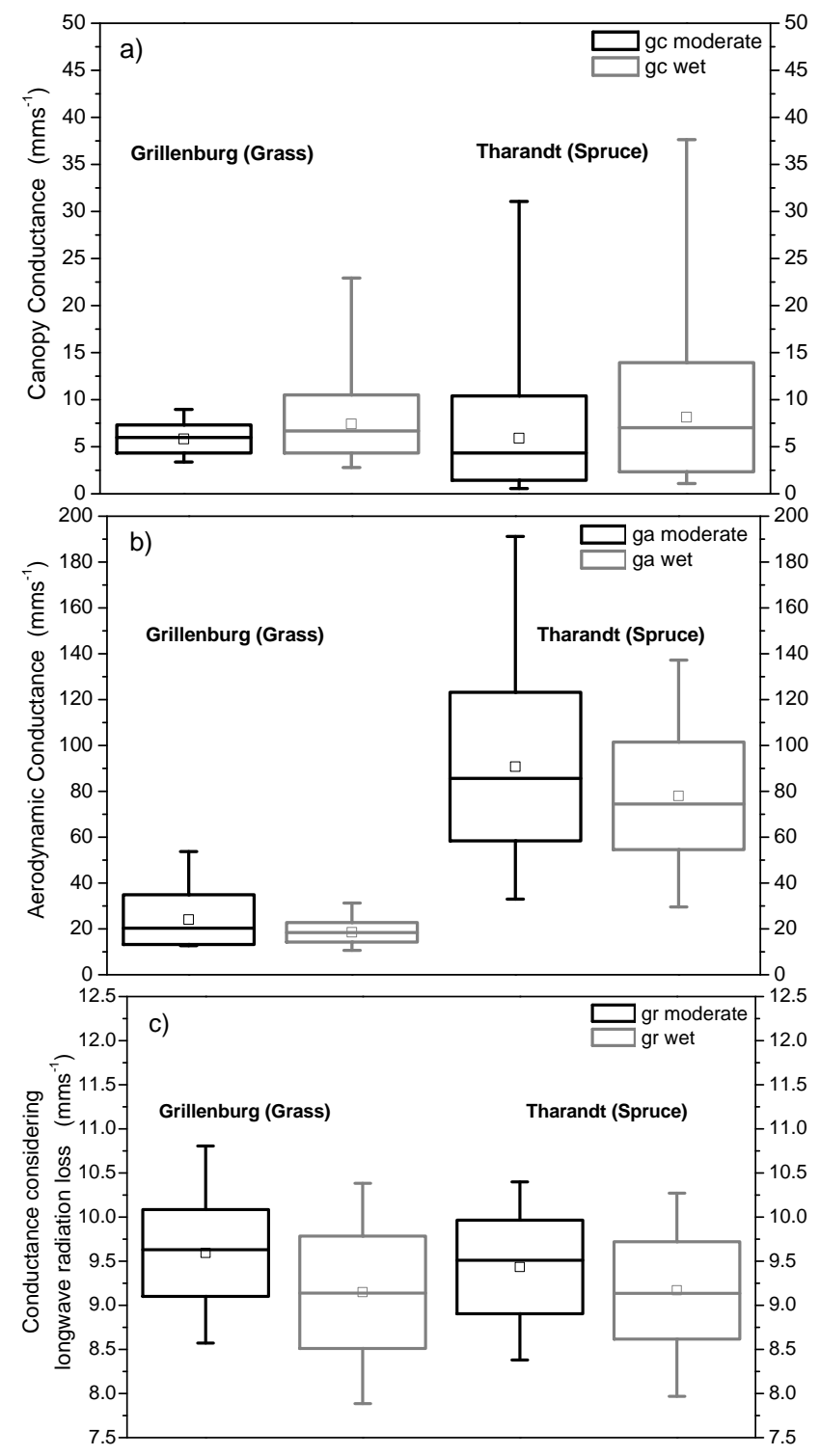

Fig. 3. Canopy (a), aerodynamic (b) and long wave radiation transfer conductance (c) derived from measurements (half hour means) at the Anchor Station Grillenburg (grass, left side) and Tharandt (spruce, right side) during the summer season 2007 (for further information see caption of Fig. 2).

are between 0.47 and 0.32 for grass as well as between 0.19 and 0.11 for spruce (see also Table 2). The absolute difference of omega between the two soil moisture regimes is higher for the grass canopy (about 0.1, for spruce: 0.08 to 0.05 ) but the relative change is higher for the spruce canopy (about $30 \%$, for grass: 10 to $24 \%$ ).

In most extreme cases the omega differences (half-hour means) between the modifications are about 0.16 for the spruce site and about 0.18 for the grass site.

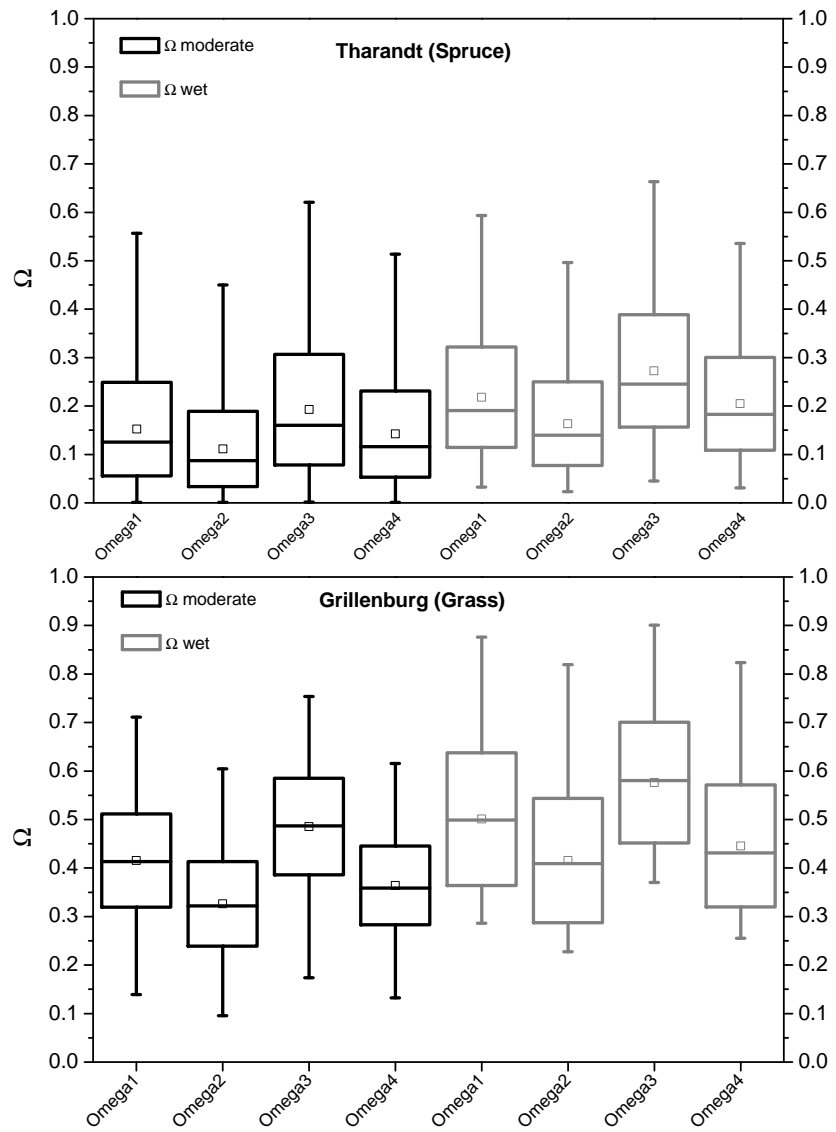

Fig. 4. Decoupling coefficient derived from measurements (half hour means) at the Anchor Station Grillenburg (grass, panel above) and Tharandt (spruce, panel below) during the summer season 2007 (for further information see caption of Fig. 2).

3.2 Comparison of Omega approaches for different land uses and soil moisture regimes using short-term measurements and simulations in June 2000

To compare measurements and HIRVAC simulations omega was calculated for the different modifications at the spruce site Tharandt and at the grass site Melpitz in the period from 18 to 21 June 2000. This sunny period (Fig. 5) was exceptionally warm with maximum temperatures up to 33 degrees Celsius at the Tharandt site (Fig. 6 above) as well as 35 degrees (air temperature at $2 \mathrm{~m}$ height) and 40 degrees (temperature of the grass surface) at the Melpitz site (Fig. 6 below). This high temperature level was combined with advection of a dry air mass which resulted in a continuous increase of vapour pressure deficit (vpd) up to a maximum of about $40 \mathrm{hPa}$ (Tharandt) and $48 \mathrm{hPa}$ (Melpitz) on the last day of the observation period. The high insolation on the partially open soil surface at the Melpitz site led to a fast dehydration of the grassland (episodic measurements of SWC with TDR probe showed values below $9 \%$ which is comparable with a matrix 

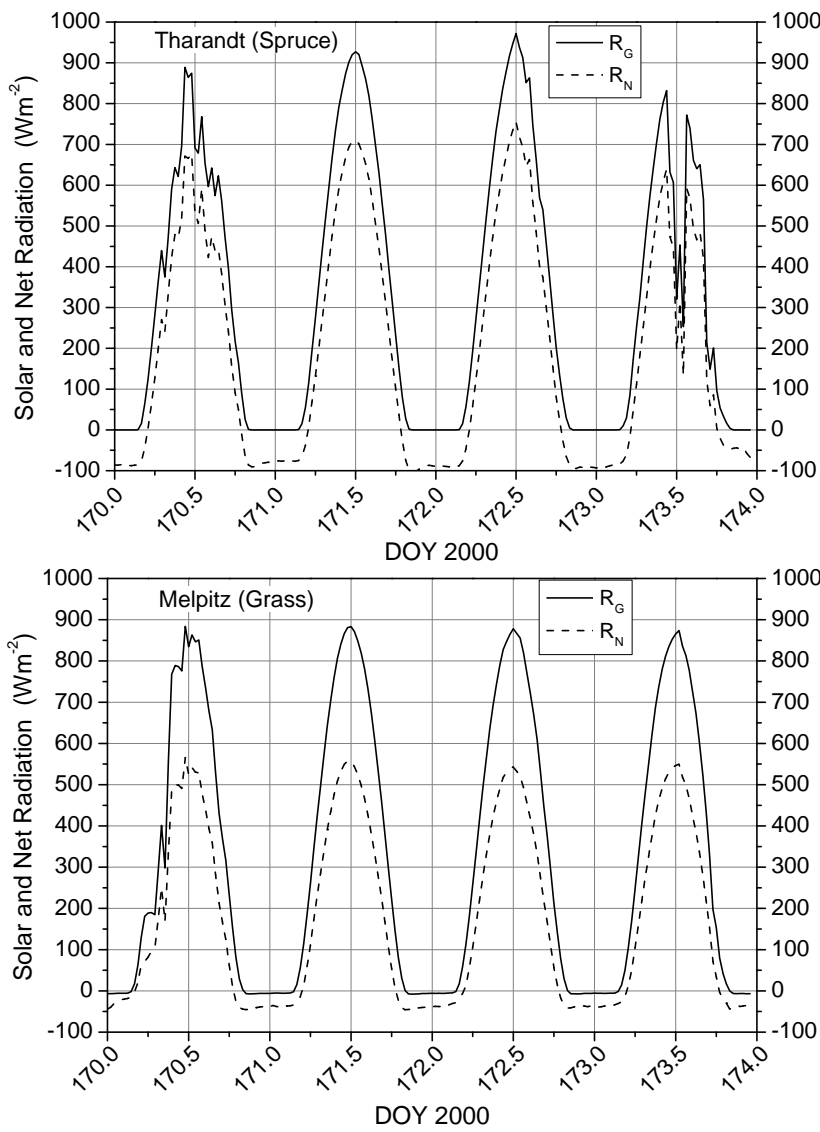

Fig. 5. Solar and Net Radiation at the Anchor Station Tharandt (Spruce, minor water limitation, panel above) and at the Melpitz experimental site (Short Grass, strong water limitation, panel below) used for model input in HIRVAC during the investigation period 18 to 21 June 2000.

potential between -200 and $-300 \mathrm{kPa}$ for sandy loam) and a low latent heat flux (Fig. 7, bottom panel). At the same time, the spruce stand at the Tharandt site did not show remarkable water problems (high LE, Fig. 7, top panel) because of the sufficient soil water content in the root zone (matrix potential about $-90 \mathrm{kPa}$ ).

The large differences in measured LE are combined with divergent canopy conductance and decoupling coefficients. In Fig. 8 the omega factors based on half-hour means between 09:00 and 16:00 local time (LT) are compared for the original approach after McNaughton and Jarvis (1983, Eq. 1) and the three modifications (Eqs. 2 to 4), whereas the numeric index at the omega symbols in the graphic legend refers to the used equations. The results illustrate expected differences in omega between the aerodynamically rough forest site at the Anchor Station Tharandt without water stress and the smooth grass surface at the Melpitz site with beginning water stress. The first mentioned site demonstrates the good ability of forests to control the transpiration
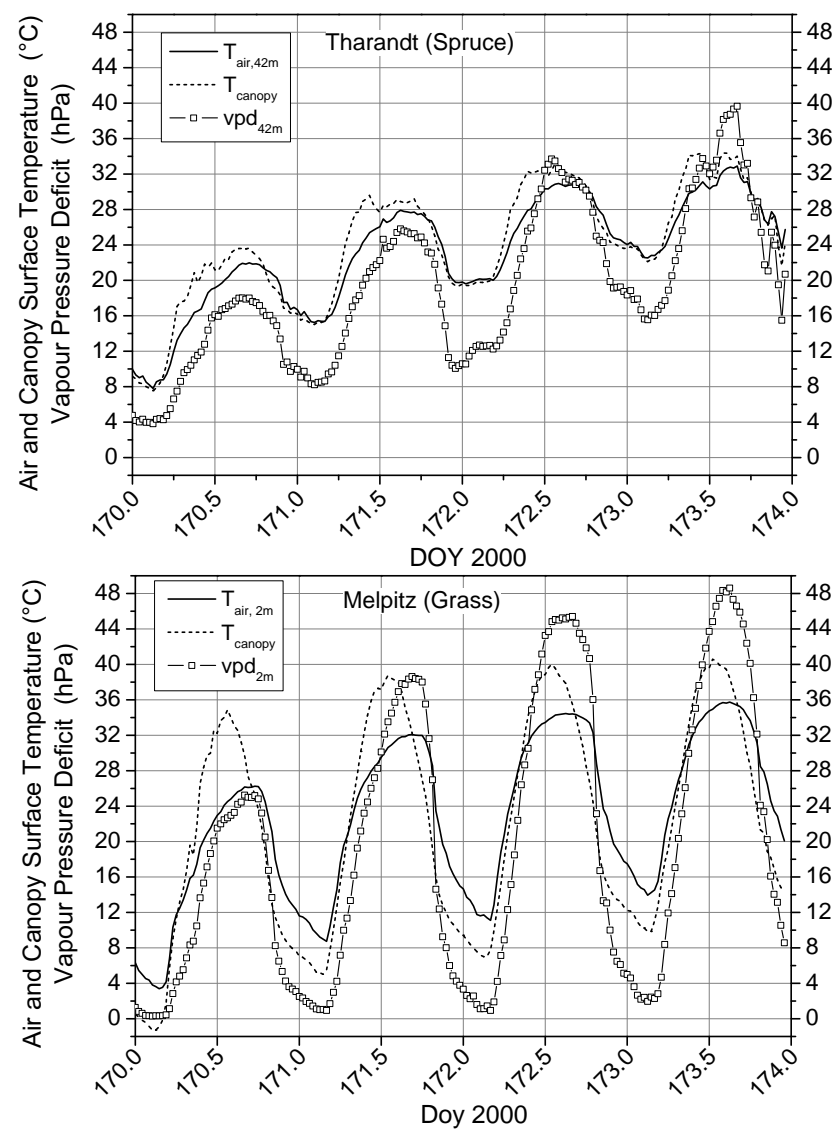

Fig. 6. Air and canopy temperature and saturation deficit (vpd) at the Anchor Station Tharandt (spruce, minor water limitation, panel above) and at the Melpitz experimental site (short grass, strong water limitation, panel below) used for calculation of omega during the investigation period 18 to 21 June 2000.

at leaf surface level by opening and closing the stomata combined with low values of the decoupling coefficient. Accordingly, the second site shows the stronger dependence of surface evapotranspiration of a grass site on available energy combined with relatively high mean values of omega. This results in distinctly higher omega values for the grass site in Melpitz during the complete investigated period.

The various modifications of omega lead to different deviations from the origin approach. In Fig. 9 the omega values of the three modifications (referring to Eqs. 2 to 4 and Fig. 8) are plotted versus the original omega approach (Eq. 1). The results show that the absolute differences between these approaches increase continuously with increasing omega ranging from 0 to 0.35 and remain constant for higher values of omega. At the forest site the increasing differences of omega are possibly caused by a more random link between canopy $\left(g_{c}\right)$ and aerodynamic conductance $\left(g_{a}\right)$ due to a reduced $g_{c}$ for higher values of $g_{a}$ (Fig. 10 above). This fact shows the ability of forests to control transpiration (Martin, 1989) 

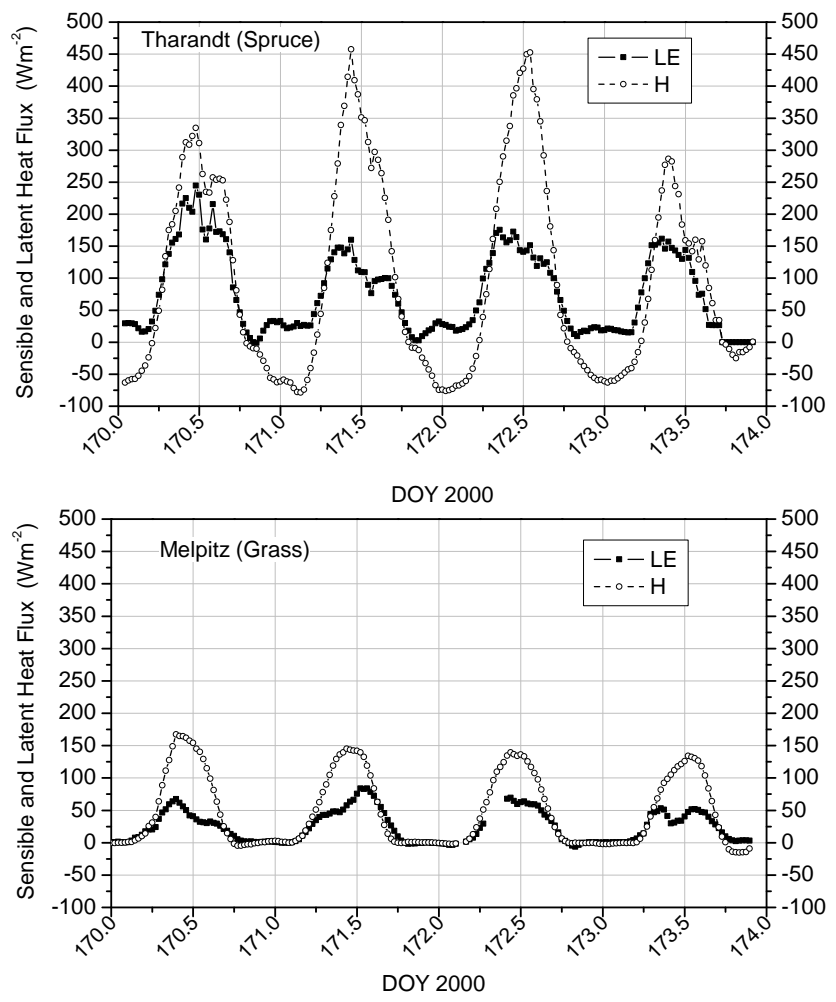

Fig. 7. Three-hours running mean of sensible $(\mathrm{H})$ and latent heat flux (LE) at the Anchor Station Tharandt (spruce, minor water limitation, panel above) and at the Melpitz experimental site (short grass, strong water limitation, panel below) during the investigation period 18 to 21 June 2000. (Note: grass measurements are based on raw eddy covariance without spectral correction.)

and to avoid high transpiration losses caused by higher wind speed in the tree crowns (Bladon et al., 2006). For higher values of $g_{a}$ combined with low $g_{c}$ the differences in the omega approaches become increasingly insignificant.

The more synchronous change of $g_{a}$ and $g_{c}$ at the grass site (Fig. 10 below) leads to a more constant relation between $g_{a}$ and $g_{c}$ in Eqs. (1) to (4) and therefore to relatively stable differences between the calculated omega values for the same meteorological conditions.

To compare the different omega approaches for the forest and the grass site combined with different soil moisture regimes, several simulations with the vegetation boundary layer model HIRVAC were realised.

Figure 11 shows the dependence of omega on the used calculation for a spruce canopy (adapted to the conditions at the Tharandt site) and a grass site (adapted to the Melpitz field site). The index number in the graphic legend corresponds to the number of equation used for the calculation of omega. Furthermore the legend "simulation" describes the calculation of transpiration (and, hence, of canopy conductance) based on the output of the gas exchange model PSN6.

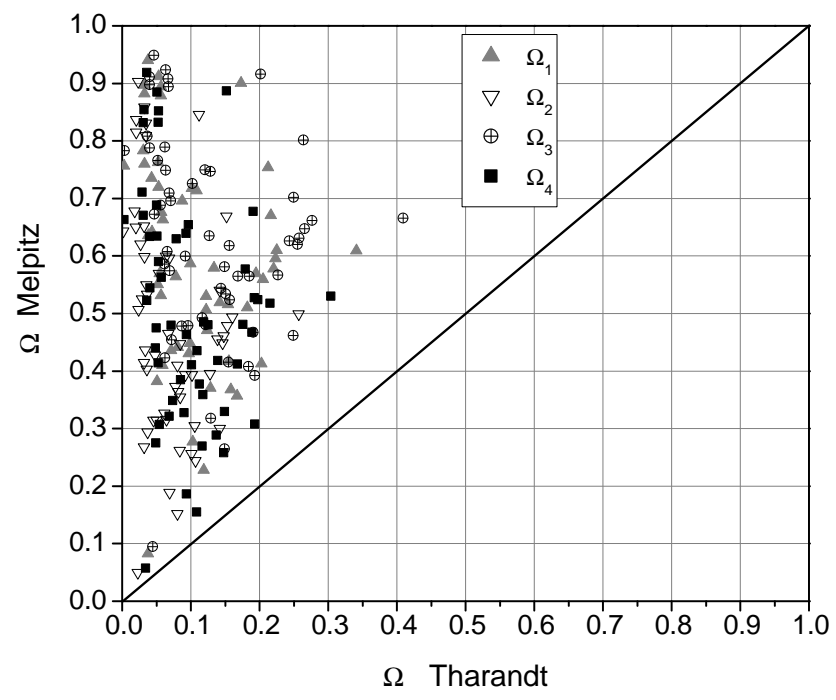

Fig. 8. Comparison of omega calculations according to Eqs. (1) to (4) and based on measurements at the Anchor Station Tharandt and at the Melpitz experimental site for the investigation period 18 to 21 June 2000 (half-hour means from 09:00 to 16:00 LT).

Table 3. Mean values (based on half-hour means between 09:00 and 16:00 LT) and standard deviation of the omega approaches according to Eqs. (1) to (4). Comparison between measurements and simulation in the period from 18 to 21 June 2000.

\begin{tabular}{|c|c|c|}
\hline \multicolumn{3}{|c|}{$\Omega($ Mean $+/-$ standard deviation $)$} \\
\hline \multirow{2}{*}{$\begin{array}{l}\text { Type of data set - } \\
\text { Omega approach }\end{array}$} & \multicolumn{2}{|c|}{ Type of canopy } \\
\hline & Spruce & Grass \\
\hline Simulation -1 & $0.07 \pm 0.02$ & $0.56 \pm 0.10$ \\
\hline Simulation - 2 & $0.05 \pm 0.01$ & $0.46 \pm 0.09$ \\
\hline Simulation -3 & $0.09 \pm 0.02$ & $0.62 \pm 0.09$ \\
\hline Simulation -4 & $0.07 \pm 0.01$ & $0.53 \pm 0.10$ \\
\hline Measurement - 1 & $0.11 \pm 0.05$ & $0.59 \pm 0.09$ \\
\hline Measurement - 2 & $0.07 \pm 0.03$ & $0.48 \pm 0.09$ \\
\hline Measurement - 3 & $0.13 \pm 0.06$ & $0.63 \pm 0.08$ \\
\hline Measurement - 4 & $0.09 \pm 0.04$ & $0.51 \pm 0.09$ \\
\hline
\end{tabular}

During the investigation period the radiation input for the model simulations was adapted to the measurements. For the purpose of comparison an ensemble mean of omega values based on measurements (half-hour means) of the investigation period (18-21 June 2000) was used.

The results of these measurements clearly show the dependence of omega on the used approach and on the type of land use (Fig. 11). For the grass canopy the mean size of omega ranges between 0.63 and 0.48 (Fig. 11a) and for the spruce site (Fig. 11b) between 0.13 and 0.07 (see also Table 3). This indicates that the application of a specific calculation routine for omega determines distinctly the quantified 

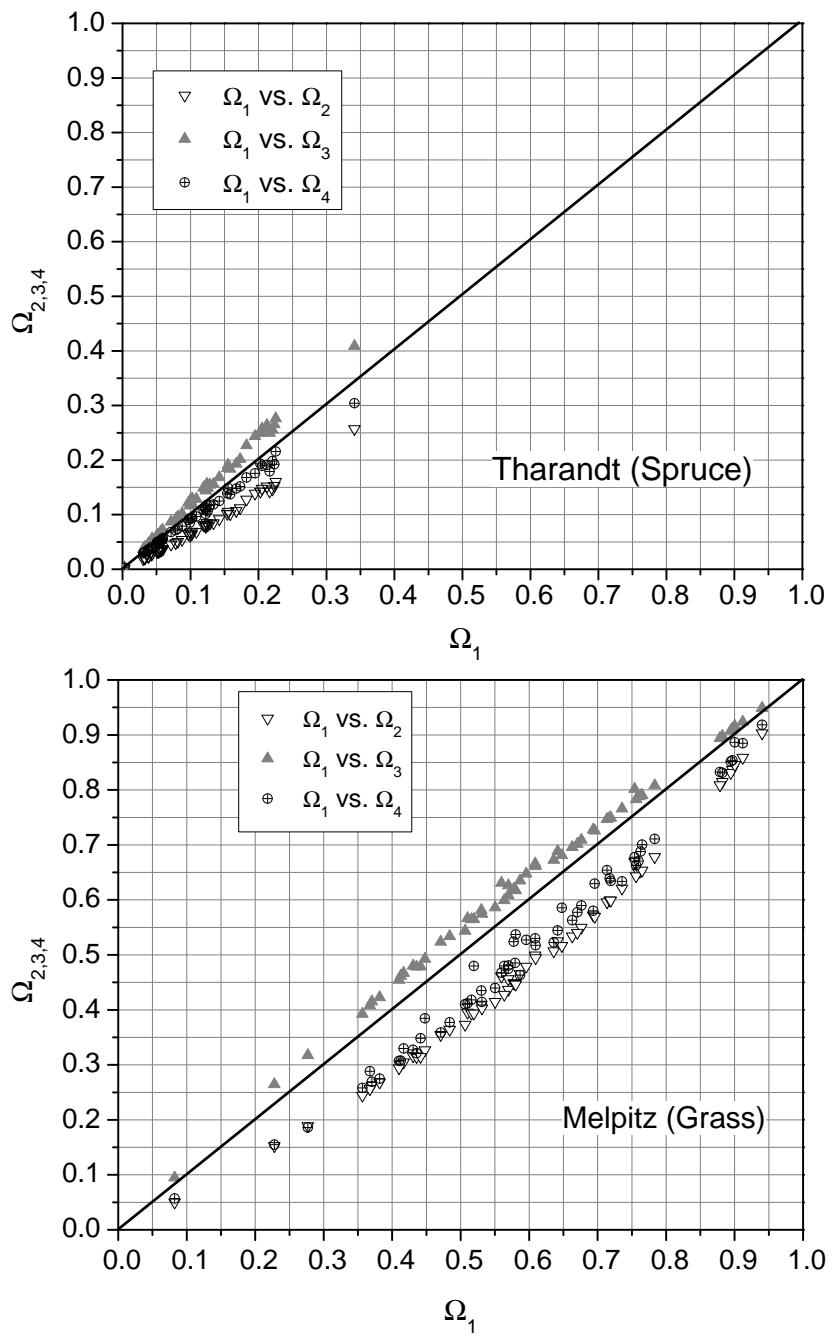

Fig. 9. Comparison of omega calculations for the Anchor Station Tharandt (panel above) and the Melpitz experimental site (panel below) for the investigation period 18 to 21 June 2000 (half-hour means from 09:00 to 16:00 LT).

degree of coupling between the investigated spruce or grass stand and the atmosphere. In the most extreme cases the measured omega values of the two contrasting land uses differ dependent on the used calculation and the time of day between 0.72 in the afternoon $\left(\Omega_{\min }\right.$ for spruce: 0.04 derived from measurements- 2 and $\Omega_{\max }$ for grass: 0.76 derived from measurements-3) and 0.07 in the morning ( $\Omega_{\max }$ for spruce: 0.26 derived from measurements- 3 and $\Omega_{\min }$ for grass: 0.33 derived from measurements-2).

For both canopies HIRVAC results match quite well with the measurements. The best agreement between the decoupling coefficients is reached for spruce in the afternoon (Fig. 11b) and for grass at noon. For the soil moisture (Fig. 11c, continuous measurements were only available for spruce) and the saturation deficit (Fig. 11d) results from
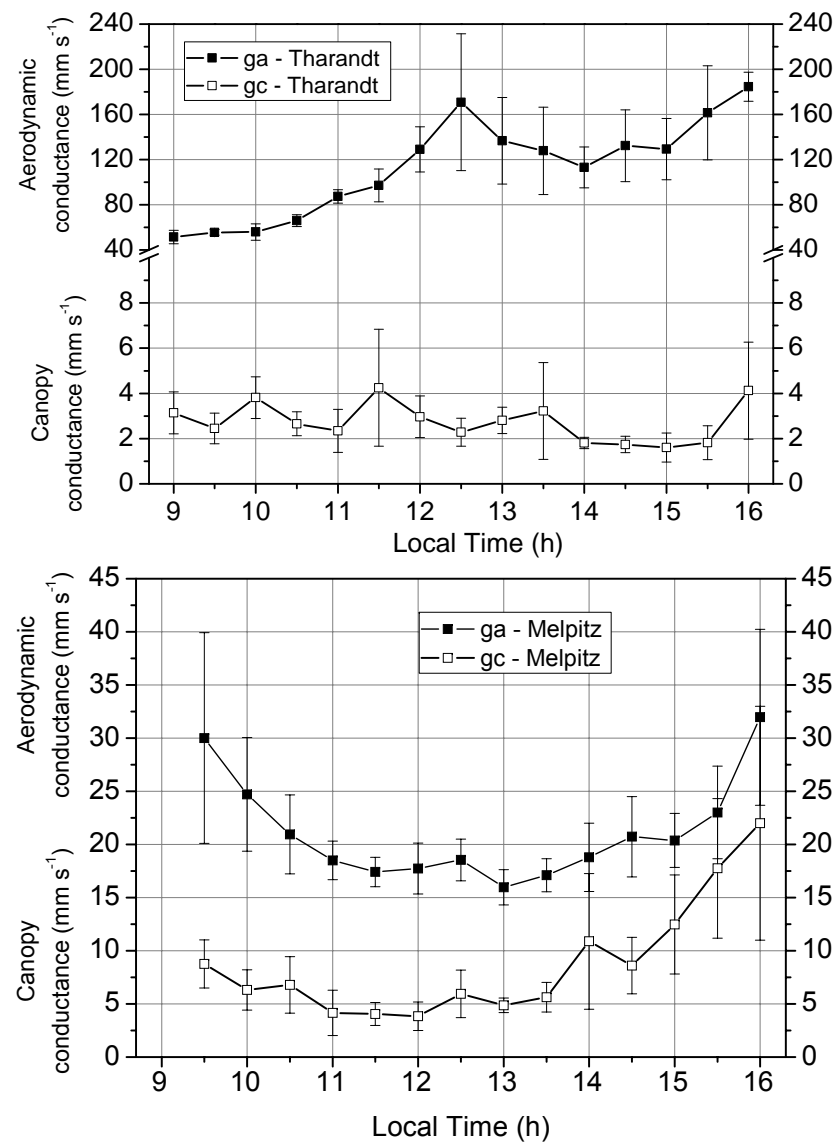

Fig. 10. Course of aerodynamic and canopy conductance at the Anchor Station Tharandt (panel above) and at the Melpitz experimental site (panel below) for the investigation period 18 to 21 June 2000 (ensemble mean and error bars from 09:00 to 16:00 LT).

simulations and measurements match also sufficiently. The highest simulated differences of $\Omega$ for the two contrasting land uses occur with 0.67 in the afternoon $\left(\Omega_{\min }\right.$ for spruce: 0.04 from simulation- 2 and $\Omega_{\max }$ for grass: 0.71 from simulation-3). During the morning hours there is even a change of ranking between the extreme omega values for the grass $\left(\Omega_{\min }=0.23\right.$ from simulation-2) and the spruce site $\left(\Omega_{\max }=0.26\right.$ from simulation -3$)$.

Finally, Table 3 summarizes the mean values and standard deviations of the simulated and measured data sets of omega discussed in Fig. 11.

3.3 Comparison of omega approaches for different land uses for a simulated dry period

The change of the decoupling coefficient and its driving factors (turbulent heat fluxes and conductance) was investigated for a synthetic summery dry period and different vegetation types using HIRVAC simulations. The forest stands were parameterised with $\mathrm{LAI}=5$, height $=30 \mathrm{~m}$ and 

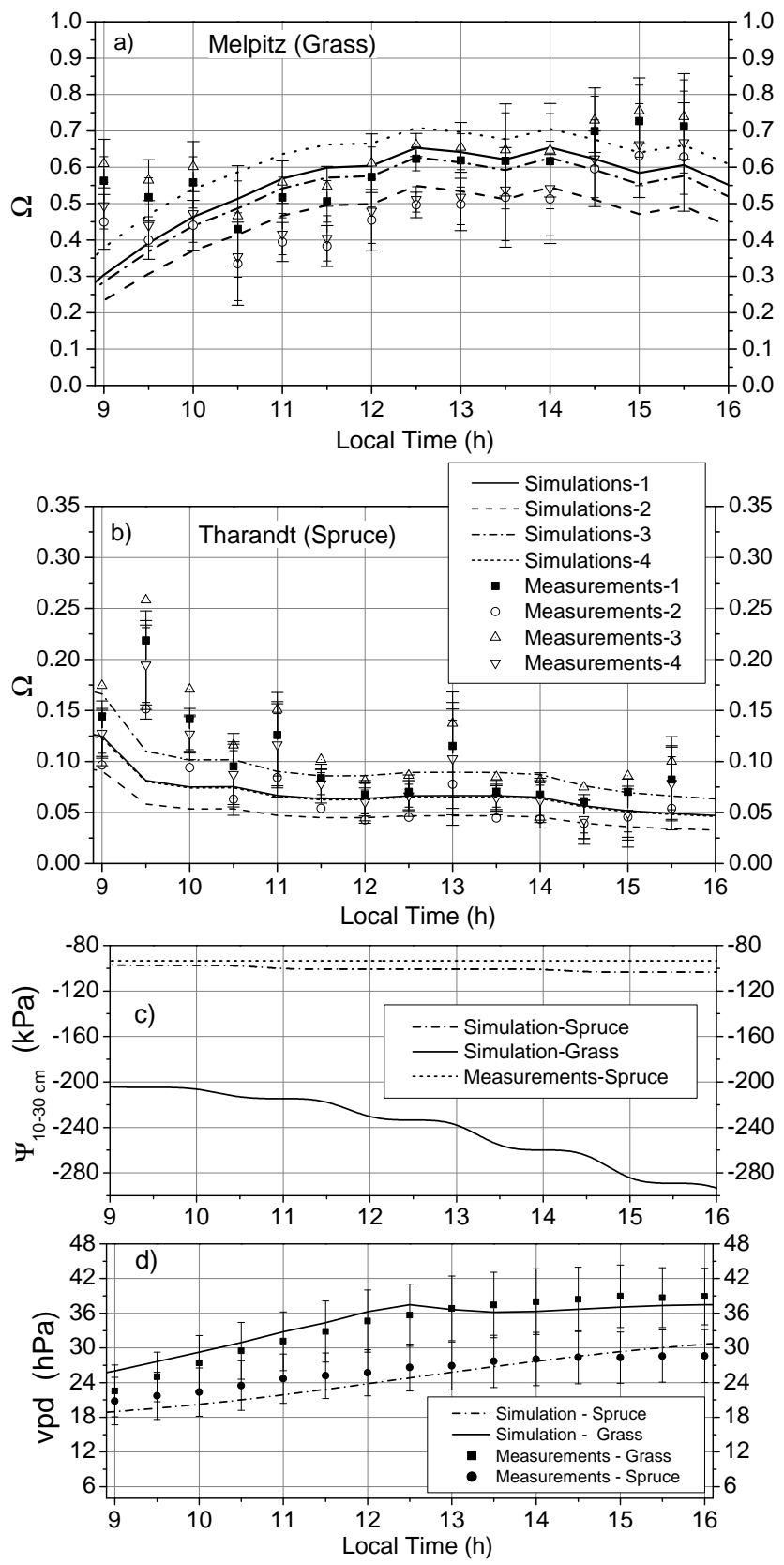

Fig. 11. Daily course of the decoupling coefficient $(\mathbf{a}, \mathbf{b})$ for the four different omega equations, as well as soil matrix potential (c) and saturation deficit (d): HIRVAC simulations for dry soil conditions compared with measurements (period 18 to 21 June 2000) from the spruce site in Tharandt and the grass field site in Melpitz.

crown cover $=70 \%$, the parameters of the grass canopy were: $\mathrm{LAI}=4$, height $=0.15 \mathrm{~m}$ and fraction of vegetation $=70 \%$.

Figure 12 shows the course of sensible heat flux $\mathrm{H}$ (Fig. 12a) and evapotranspiration ET (Fig. 12b) for three forest canopies (spruce, pine and beech) and a grass site during this simulated dry period. The results clearly illustrate the
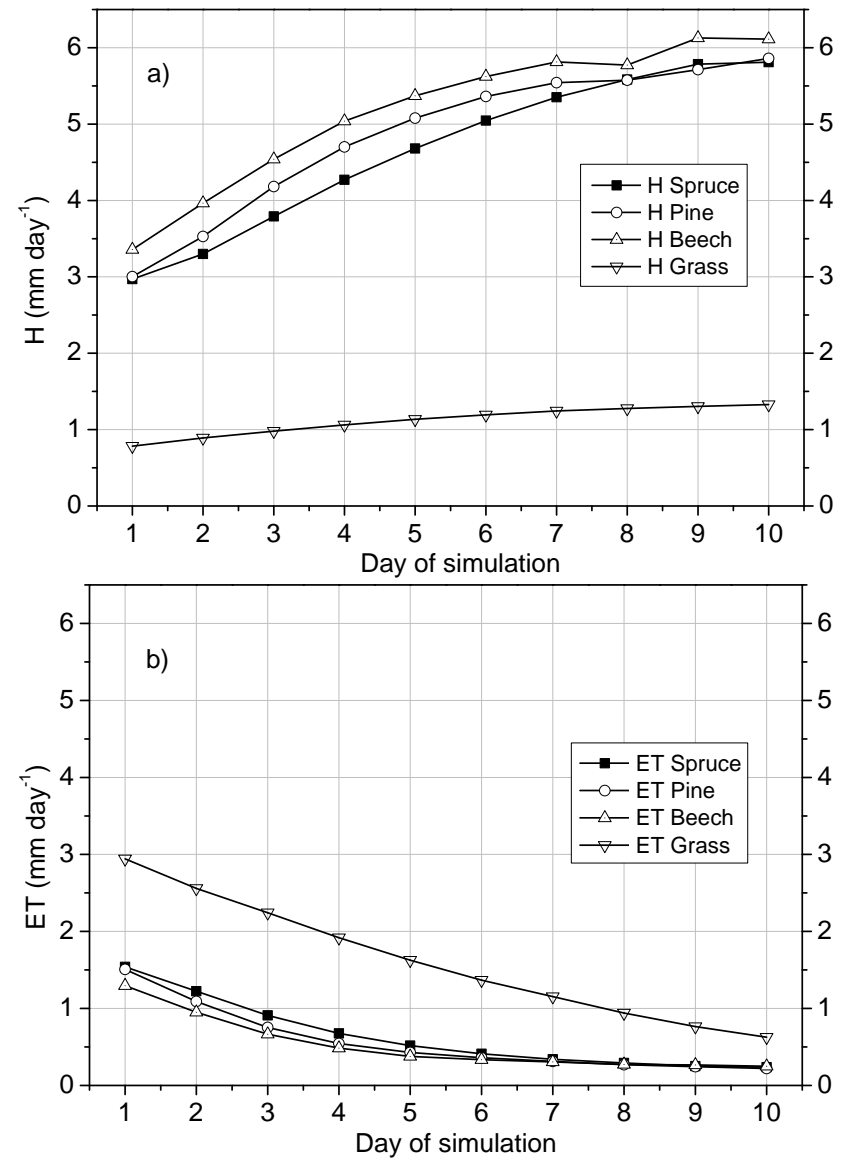

Fig. 12. Daily sum of sensible heat flux (a) and evapotranspiration (b) during a summery dry period. HIRVAC simulations for spruce, pine and beech with the stand parameters: height $=30 \mathrm{~m}, \mathrm{LAI}=5$, crown cover $=70 \%$, as well as for grass with height $=0.15 \mathrm{~m}, \mathrm{LAI}=4$, fraction of vegetation $=70 \%$.

different reaction of these vegetation types to the increasing drying out of the soil and the atmosphere. For the forest sites the ET values decrease from about $1.5 \mathrm{~mm} \mathrm{day}^{-1}$ to $0.25 \mathrm{~mm}$ at the ninth simulation day. At the same simulation period ET falls at the grass site from $3 \mathrm{~mm} \mathrm{day}^{-1}$ to $0.7 \mathrm{~mm}$, and the sensible heat flux $\mathrm{H}$ increases from about $3 \mathrm{~mm}$ (forest) and $0.8 \mathrm{~mm}$ (grass) to about $6 \mathrm{~mm}$ (forest) and $1.3 \mathrm{~mm}$ per day (grass). Among the forest canopies the spruce stand shows the strongest reaction to the change of soil moisture. This is probably due to the parameterisation of the gas exchange model PSN6.

The interaction with decreasing soil moisture and canopy conductance $\left(g_{c}\right)$ during this simulation period is shown very well in Fig. 13a. On the first simulation day the soil moisture is high which leads to a high $g_{c}$ of all canopies (grass: $81.6 \mathrm{mms}^{-1}$, spruce: $61.2 \mathrm{mms}^{-1}$, pine: $47.9 \mathrm{mms}^{-1}$ and beech: $40.0 \mathrm{mms}^{-1}$ ). The sharp decrease of ET during the drying out of the soil yields a rapid decrease of $g_{c}$. Under 
dry soil conditions (from the sixth to the ninth simulation day, Fig. 13a) the canopy conductance of the forest sites (5.5 to $\left.1.9 \mathrm{mms}^{-1}\right)$ is distinctly lower as for the grass site $(12.5$ to $8.9 \mathrm{mms}^{-1}$ ). This demonstrates the different strategies of these vegetation types to manage the water budget under dry soil and atmospheric conditions. As already mentioned for the heat fluxes the spruce stand shows the strongest change of $g_{c}$ among the tree types described.

Except for a short reaction during the first three simulation days the aerodynamic conductance $g_{a}$ is relatively constant and shows the expected differences between the forest and the grass canopies (Fig. 13b). During the dry period (simulation day 6-9) $g_{a}$ ranges between 94 (beech) and $102 \mathrm{mms}^{-1}$ (pine) for the trees and around $13.5 \mathrm{mms}^{-1}$ for grass.

Finally, Fig. 14 shows the change of the decoupling coefficient (based on half-hour means between 10:00 and 15:00 LT) for the four variants of omega (Eqs. 1 to 4), which are applied to the different land uses as mentioned above. The course of omega during the simulation period is similar for the tree types with the same ranking for the different calculations of the decoupling coefficient: the highest value is related to the second modification of the original approach (the third calculation in the graph key), and the lowest value results from the first modification (second calculation). Omega starts with a value between 0.73 (spruce, third variant of omega calculation, Fig. 14a) and 0.47 (beech, second variant, Fig. 14b). This result is a hint to a moderate coupling between the vegetation and the atmosphere under a sufficient water supply. During the continuous drying out of the soil the decoupling coefficients decrease sharply and converge. At the end of the HIRVAC simulation they range between 0.13 (spruce, third variant of omega calculation, Fig. 14a) and 0.05 (beech, second variant, Fig. 14b).

The simulated decoupling coefficients differ strongly between the grass site and the forest stands. At the grass canopy omega changes during the simulation from about 0.95 to values between 0.64 and 0.82 . The ranking between the calculation variants is the same as for the investigated tree types but the difference between the modifications increases during the simulation. A possible reason could be the higher sensitivity of omega to changes in additive elements of the original equation caused by the significantly smaller aerodynamic conductance in relation to the trees.

\subsection{Comparison of HIRVAC simulations with results from literature}

The simulated values for omega are comparable with results from literature. Bladon et al. (2006) found, for example, omega values between 0.16 and 0.40 for different boreal tree species (Picea glauca, Betula papyrifera and Populus balsamifera). Also Herbst (1995) observed for the decoupling coefficient long-term averages of 0.20 for a beech stand ( $\mathrm{Fa}$ gus sylvatica L.), and Martin et al. (2001) determined mean omega values for an old coniferous stand between 0 and 0.2
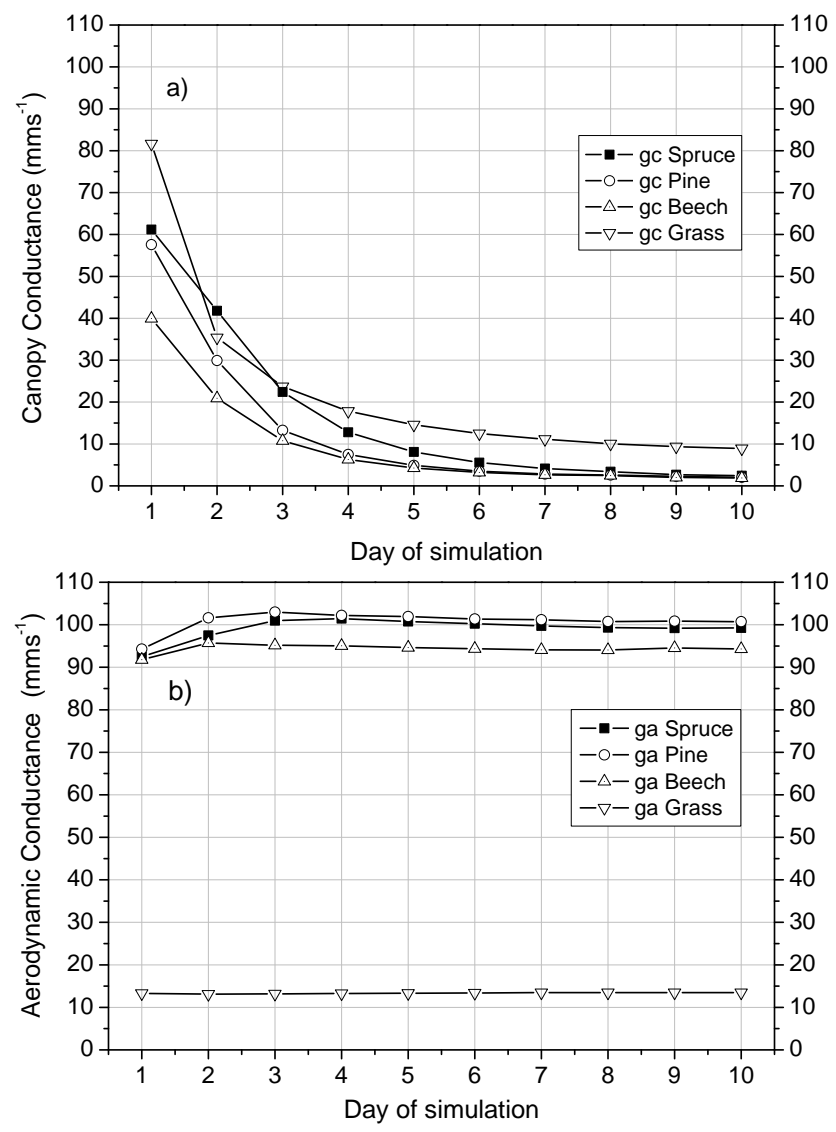

Fig. 13. Canopy (a) and aerodynamic conductance (b) (Mean of half hour averages between 10:00 and 15:00 LT) during a summery dry period. HIRVAC simulations for spruce, pine, beech and grass with the stand parameters as described in Fig. 12.

which is a comparable range to the simulations for the spruce stand at the Anchor Station Tharandt. Furthermore, the authors detected a short-term variability of omega due to a high variability of aerodynamic conductance (that means of the wind speed) above the trees. White et al. (2000) demonstrated that the size of omega strongly depends on the used approach for calculation of the canopy conductance (in layers or integrated over the whole canopy) and found mean omega values for an Eucalyptus stand between 0.63 and 0.26, which depends on the used approach. Wullschleger et al. (2000) derived the decoupling coefficient for different seasons and daytimes and showed that the size of omega mainly depends on the interdiurnal differences in radiation input as well as on the time of day. The calculated variability of omega for one day ranged between 0 and 0.3 for the studied red maple stand which is adequately comparable with the variability of HIRVAC simulations for a forest canopy. A similar result of daytime variability of omega was found in measurements for Nothofagus fusca trees by Köstner et al. (1992). Finally, some of the above mentioned authors stated the strong 

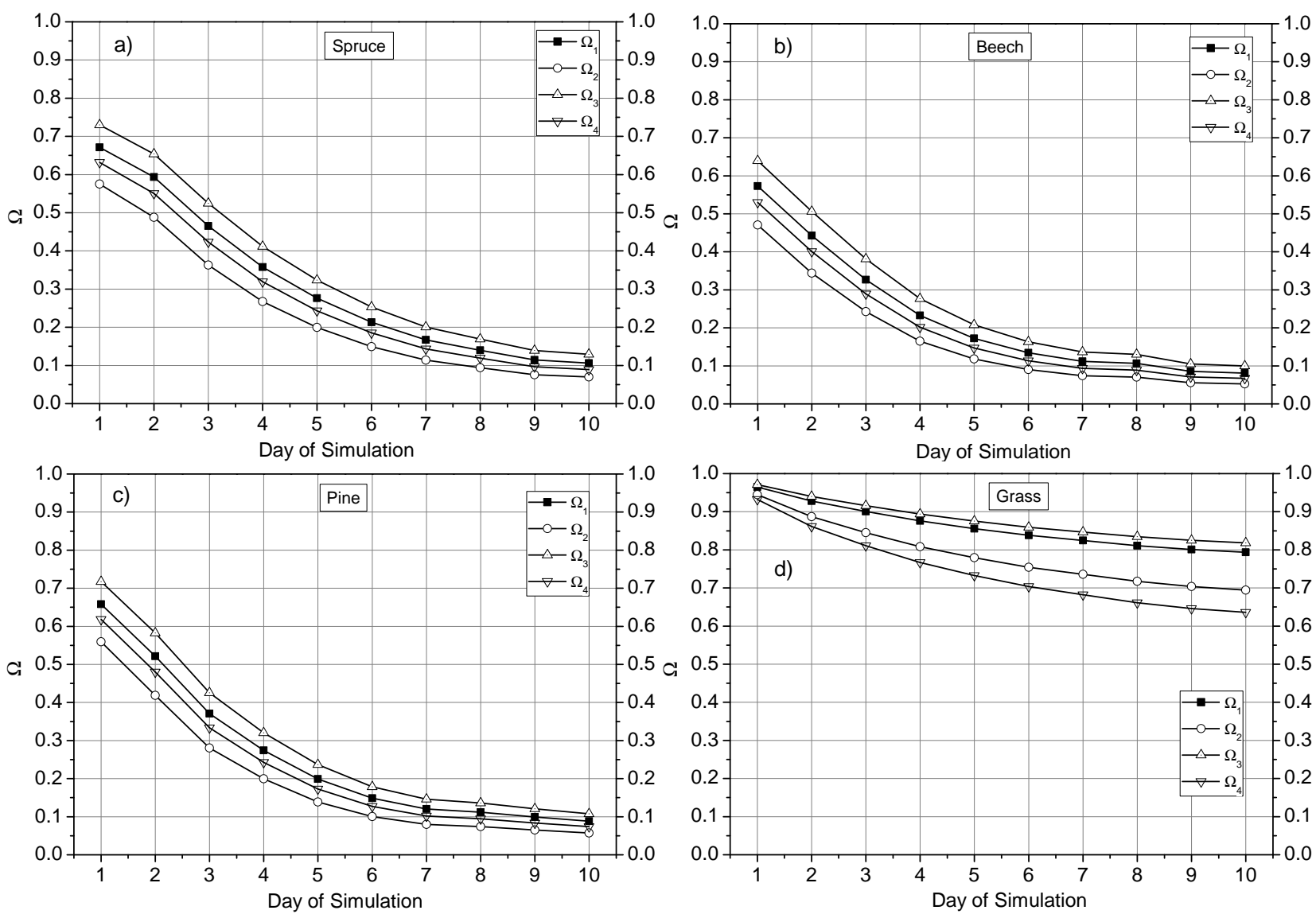

Fig. 14. Decoupling coefficients using four different approaches (Mean of 15 min values between 10:00 and 15:00 LT) during a summery dry period. HIRVAC simulations for spruce (a), beech (b), pine (c) and grass (d) with the stand parameters as described in Fig. 12.

dependence of omega on the soil and air moisture conditions and on the observed vegetation types which is in the same range as the diurnal and seasonal variability of omega.

\section{Conclusions}

The simulated mean absolute values of omega agree fairly well with results from literature and show the applicability of the model HIRVAC to compare the different modifications of omega calculation in this study. Also the comparison of the different omega applications with measurements at the spruce site in Tharandt and at the grass sites in Grillenburg and Melpitz shows that the soil moisture is an important controlling factor for the coupling mechanism between the vegetation and the atmosphere.

The simulations of omega using different deviations from the origin approach after McNaughton and Jarvis lead to pronounced differences, which depends as well on the considered vegetation species as on the soil and atmospheric conditions. As an example the maximum differences range for the sunny period in June 2000 at the spruce site in Tharandt between 0.06 (morning hours) and 0.04 (afternoon). For the grass site in Melpitz the differences are around 0.16 over the day. Regarding the mean simulation values of omega for the spruce $(0.07)$ and for the grass site (0.54) the maximum relative differences between the modifications are between 85 and $57 \%$ for spruce and around $30 \%$ for the grass canopy.

The two regarded canopies react distinctly different to the atmospheric and soil conditions throughout the simulated nine day dry period (Fig. 14). Under moderate soil moisture conditions at the beginning of simulation mean omega values of the trees and grass are about 0.6 and 0.95 . This is a hint to a low coupling with the atmosphere. During the continuous drying out of the soil and the atmosphere the control mechanism of trees to avoid water losses lead to a sharp increase of omega difference between the grass and the forest canopies (omega value at the end of simulation: about 0.08 for the trees and between 0.63 and 0.82 for grass).

Under extremely dry conditions the choice of a special omega modification becomes more important if the decoupling coefficient is calculated at a grass site: The omega differences between the modifications increases from about 
$0.05(6 \%)$ at the beginning to about $0.19(26 \%)$ at the end of the simulation.

In comparison to other causes of the omega variability (plant type, soil and atmospheric conditions) the absolute deviations of omega due to the used approach are mostly smaller. But in contrast to the first mentioned reasons the applied calculation routine determines the change in the longterm mean of omega. For the regarded summer season in 2007 the mean decoupling coefficients range for spruce and moderate soil wetness between 0.11 and 0.19 and for wet soil between 0.16 and 0.27 . For grass the same quantities range from 0.32 to 0.47 (moderate soil wetness) as well as from 0.42 to 0.58 (wet soil). That indicates a maximum relative change of omega of about $70 \%$ for spruce and about $45 \%$ for grass. At last, these differences could lead to another interpretation of the coupling conditions, to a changed estimation of water stress tolerance of the observed vegetation as well as to a deviant determination of the degree of landscape heterogeneity.

This study does not aim to a general criticism of the different omega modifications, but we want to focus potential applicants of the omega concept on this problem. Generally, it is not always clear why the different authors used other approaches than the original one of McNaughton and Jarvis, so that the results obtained with the different omega modifications cannot be compared quantitatively. Perhaps, the particular unclarity in the literature, about which equation should be used, arises from the fact that it is not clarified in general how the concept of differentiation between one- and doublesided water vapour transfer of hypostomatous and amphistomatous leaves should be treated at the canopy scale.

However, on the other hand, our results show that the well known dependencies between the decoupling coefficient and the controlling factors of the atmosphere and the soil are not changed dramatically if another approach is used.

To avoid misinterpretations of results, potential applicants of the omega concept should control carefully which equation of omega is used for their studies and which omega approach is applied in the literature used for comparison.

Because the majority of the authors use the original approach after McNaughton and Jarvis we also recommend the application of this approach or optionally of the extended equation after Martin (1989) which additionally includes the radiation effect on aerodynamic coupling.

\section{Appendix A}

List of symbols and abbreviations

\begin{tabular}{|c|c|c|}
\hline Abbreviations & Definition & unit \\
\hline DOY & Day of the Year & \\
\hline HIRVAC & $\begin{array}{l}\text { High Resolution Vege- } \\
\text { tation Atmosphere Cou- } \\
\text { pler }\end{array}$ & \\
\hline LT & Local Time & $\mathrm{h}$ \\
\hline PSN6 & $\begin{array}{l}\text { single leaf gas exchange } \\
\text { model used in HIRVAC }\end{array}$ & \\
\hline TDR & $\begin{array}{l}\text { Time Domain Reflec- } \\
\text { tometer }\end{array}$ & \\
\hline SD & Standard Deviation & \\
\hline SVAT & $\begin{array}{l}\text { Soil Vegetation Atmo- } \\
\text { sphere Transfer }\end{array}$ & \\
\hline \multicolumn{3}{|l|}{ Greek symbols } \\
\hline$\gamma$ & psychrometric constant & $\mathrm{Pa} \mathrm{K}^{-1}$ \\
\hline$\varepsilon$ & $\begin{array}{l}\text { dimensionless coeffi- } \\
\text { cient } \varepsilon=s / \gamma\end{array}$ & \\
\hline$\Lambda$ & leaf area index & $\mathrm{m}^{2} \mathrm{~m}^{-2}$ \\
\hline$\rho$ & air density & $\mathrm{kg} \mathrm{m}^{-3}$ \\
\hline$\sigma$ & $\begin{array}{l}\text { Stefan-Boltzmann } \\
\text { constant }\end{array}$ & $\mathrm{W} \mathrm{m}^{-2} \mathrm{~K}^{-4}$ \\
\hline$\Theta$ & potential temperature & $\mathrm{K}$ \\
\hline$\Omega$ & decoupling coefficient & \\
\hline$\Psi$ & actual matrix potential & $\mathrm{MPa}, \mathrm{kPa}$ \\
\hline$\Psi_{F C}$ & $\begin{array}{l}\text { matrix potential in the ef- } \\
\text { fective root zone at field } \\
\text { capacity }\end{array}$ & $\mathrm{MPa}, \mathrm{kPa}$ \\
\hline \multicolumn{3}{|l|}{ Latin symbols } \\
\hline$B_{l w}$ & $\begin{array}{l}\text { longwave atmospheric } \\
\text { radiation }\end{array}$ & $\mathrm{W} \mathrm{m}^{-2}$ \\
\hline$c$ & $\begin{array}{l}\text { electron transport capac- } \\
\text { ity during photosynthesis } \\
\text { process }\end{array}$ & \\
\hline$c_{d}$ & drag coefficient & \\
\hline$c_{p}$ & $\begin{array}{l}\text { specific heat capacity of } \\
\text { dry air }\end{array}$ & $\mathrm{J} \mathrm{kg}^{-1} \mathrm{~K}^{-1}$ \\
\hline ET & evapotranspiration & $\mathrm{mm} \mathrm{day}^{-1}$ \\
\hline$f$ & coriolis parameter & $\approx 10^{-4} \mathrm{~s}^{-1}$ \\
\hline$f_{v c}$ & carboxylase capacity & \\
\hline$g_{a}$ & $\begin{array}{l}\text { aerodynamic conduc- } \\
\text { tance for sensible heat } \\
\text { flux }\end{array}$ & $\mathrm{ms}^{-1}$ \\
\hline$g_{b}$ & $\begin{array}{l}\text { aerodynamic boundary } \\
\text { layer conductance of the } \\
\text { canopy }\end{array}$ & $\mathrm{ms}^{-1}$ \\
\hline$g_{c}$ & canopy conductance & $\mathrm{ms}^{-1}$ \\
\hline
\end{tabular}




\begin{tabular}{|c|c|c|c|c|c|}
\hline Abbreviations & Definition & unit & Abbreviations & Definition & unit \\
\hline \multicolumn{3}{|l|}{ Latin symbols } & \multicolumn{3}{|l|}{ Latin symbols } \\
\hline$g_{\mathrm{fac}}$ & $\begin{array}{l}\text { linear factor of the em- } \\
\text { pirical model to de- }\end{array}$ & $\mathrm{ms}^{-1}$ & $r_{b}$ & $\begin{array}{l}\text { boundary layer resis- } \\
\text { tance }\end{array}$ & $\mathrm{sm}^{-1}$ \\
\hline & scribe stomata con- & & $r_{c}$ & canopy resistance & $\mathrm{sm}^{-1}$ \\
\hline & ductance in PSN6 & & $r_{s}$ & stomata resistance & $\mathrm{sm}^{-1}$ \\
\hline$g_{r}$ & $\begin{array}{l}\text { long wave radiation } \\
\text { transfer conductance }\end{array}$ & $\mathrm{ms}^{-1}$ & $r_{v}$ & $\begin{array}{l}\text { resistance of evapo- } \\
\text { transpiration }\end{array}$ & $\mathrm{sm}^{-1}$ \\
\hline & of the canopy & & $s$ & slope of the saturation & $\mathrm{Pa} \mathrm{K}^{-1}$ \\
\hline$g_{s}$ & stomata conductance & $\mathrm{ms}^{-1}$ & & vapour pressure - tem- & \\
\hline $\mathrm{H}$ & sensible heat flux be- & $\begin{array}{l}\mathrm{W} \mathrm{m}^{-2} \\
\text { or }\end{array}$ & & perature curve & \\
\hline & face inside and a ref- & $\mathrm{mm}$ day $^{-1}$ & $\begin{array}{l}\mathrm{SWC} \\
T\end{array}$ & $\begin{array}{l}\text { soll water content } \\
\text { air temperature }\end{array}$ & $\begin{array}{l}\text { vol. } \% \\
\mathrm{~K}\end{array}$ \\
\hline & $\begin{array}{l}\text { erence layer above the } \\
\text { canopy }\end{array}$ & & $T_{0}$ & $\begin{array}{l}\text { temperature of the ac- } \\
\text { tive surface }\end{array}$ & $\mathrm{K}$ \\
\hline$j$ & $\begin{array}{l}\text { Index for inclusion the } \\
\text { plant-specific source } \\
\text { term in HIRVAC: } j=1\end{array}$ & & $T_{\text {air }, 2 \mathrm{~m}}$ & $\begin{array}{l}\text { measured air temper- } \\
\text { ature above the grass } \\
\text { site in Melpitz }\end{array}$ & ${ }^{\circ} \mathrm{C}, \mathrm{K}$ \\
\hline & $\begin{array}{l}\text { inside and } j=0 \text { above } \\
\text { the canopy }\end{array}$ & & $T_{\text {air }, 42 \mathrm{~m}}$ & $\begin{array}{l}\text { measured air tempera- } \\
\text { ture above the spruce }\end{array}$ & ${ }^{\circ} \mathrm{C}, \mathrm{K}$ \\
\hline$K$ & $\begin{array}{l}\text { turbulent-transfer co- } \\
\text { efficient for momen- } \\
\text { tum }\end{array}$ & $\mathrm{m}^{2} \mathrm{~s}^{-1}$ & $T_{\text {canopy }}$ & $\begin{array}{l}\text { stand near Tharandt } \\
\text { measured surface tem- } \\
\text { perature of the vegeta- }\end{array}$ & ${ }^{\circ} \mathrm{C}, \mathrm{K}$ \\
\hline$K_{T}$ & $\begin{array}{l}\text { turbulent-transfer co- } \\
\text { efficient heat }\end{array}$ & $\mathrm{m}^{2} \mathrm{~s}^{-1}$ & $T$ & tion at the field sites & $\mathrm{K}$ \\
\hline$K_{q}$ & $\begin{array}{l}\text { turbulent-transfer co- } \\
\text { efficient for moisture }\end{array}$ & $\mathrm{m}^{2} \mathrm{~s}^{-1}$ & & $\begin{array}{l}\text { corresponding ref- } \\
\text { erence layer above }\end{array}$ & \\
\hline$L$ & heat of vaporisation & $\mathrm{J} \mathrm{kg}^{-1} \mathrm{~K}^{-1}$ & & the canopy (bulk & \\
\hline LE & $\begin{array}{l}\text { latent heat flux be- } \\
\text { tween the active sur- } \\
\text { face inside and a ref- }\end{array}$ & $\mathrm{W} \mathrm{m}^{-2}$ & $T_{W}$ & $\begin{array}{l}\text { approach) } \\
\text { temperature of the } \\
\text { vegetation surface }\end{array}$ & K \\
\hline & erence layer above the & & $u^{*}$ & friction velocity & $\mathrm{ms}^{-1}$ \\
\hline & canopy & & $v_{g x}$ & $\mathrm{X}$-component & $\mathrm{ms}^{-1}$ \\
\hline LAD & leaf area density & $\mathrm{m}^{2} \mathrm{~m}^{-3}$ & & geostrophic & \\
\hline LAI & leaf area index & $\mathrm{m}^{2} \mathrm{~m}^{-2}$ & & speed & \\
\hline$M_{\mathrm{air}}, M_{v}$ & $\begin{array}{l}\text { molecular weight of } \\
\text { dry air and water } \\
\text { vapour }\end{array}$ & $\mathrm{g} \mathrm{mol}^{-1}$ & $v_{g y}$ & 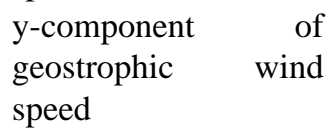 & $\mathrm{ms}^{-1}$ \\
\hline$n_{w}$ & crown cover & & vpd & vapour pressure or sat- & $\mathrm{hPa}$ \\
\hline$p$ & air pressure & $\mathrm{Pa}$ & & uration deficit & \\
\hline$q$ & $\begin{array}{l}\text { specific humidity of } \\
\text { the air }\end{array}$ & $\mathrm{kg} \mathrm{kg}^{-1}$ & $\operatorname{vpd}_{2 \mathrm{~m}}$ & $\begin{array}{l}\text { measured saturation } \\
\text { deficit above the grass }\end{array}$ & $\mathrm{hPa}$ \\
\hline$q_{s}\left(T_{0}\right)$ & $\begin{array}{l}\text { specific saturation hu- } \\
\text { midity of the active } \\
\text { surface }\end{array}$ & $\mathrm{kg} \mathrm{kg}^{-1}$ & $\operatorname{vpd}_{42 m}$ & $\begin{array}{l}\text { site in Meplitz } \\
\text { measured saturation } \\
\text { deficit above the }\end{array}$ & $\mathrm{hPa}$ \\
\hline$q_{w}$ & $\begin{array}{l}\text { specific saturation hu- } \\
\text { midity at } T_{W}\end{array}$ & $\mathrm{~kg} \mathrm{~kg}^{-1}$ & & $\begin{array}{l}\text { spruce stand near } \\
\text { Tharandt }\end{array}$ & \\
\hline $\begin{array}{l}R \\
R_{G}\end{array}$ & $\begin{array}{l}\text { gas constant of dry air } \\
\text { solar radiation }\end{array}$ & $\begin{array}{l}287 \mathrm{~J} \mathrm{~kg}^{-1} \mathrm{~K}^{-1} \\
\mathrm{~W} \mathrm{~m}^{-2}\end{array}$ & $v_{x}$ & $\begin{array}{l}\mathrm{x} \text {-component of hori- } \\
\text { zontal wind speed }\end{array}$ & $\mathrm{ms}^{-1}$ \\
\hline $\begin{array}{l}\kappa_{G} \\
R_{N}\end{array}$ & net radiation & $\mathrm{W} \mathrm{m}^{-2}$ & $v_{y}$ & $\mathrm{y}$-component of hori- & $\mathrm{ms}^{-1}$ \\
\hline$r_{a}$ & $\begin{array}{l}\text { aerodynamic resis- } \\
\text { tance for sensible heat } \\
\text { flux }\end{array}$ & $\mathrm{sm}^{-1}$ & $\mathrm{z}$ & $\begin{array}{l}\text { zontal wind speed } \\
\text { vertical coordinate in } \\
\text { HIRVAC }\end{array}$ & $\mathrm{m}$ \\
\hline
\end{tabular}


Acknowledgements. This study was partially funded by the research project "Atmosphärische Rückkoppelung" (Atmospheric feedback) of the Deutsche Forschungsgemeinschaft (grant number BE 1721/2-1), as well as by the EU project CARBOEUROPE-IP. The authors also thank PD Eva Falge from the Max Planck Institute in Mainz for the help during implementation of the PSN6 modifications in HIRVAC, Gerald Spindler from the Institute of Tropospheric Research in Leipzig for assistance during the measuring campaign at the Melpitz site, as well as two anonymous reviewers for helpful comments.

Topical Editor F. D'Andrea thanks M. Herbst and another anonymous referee for their help in evaluating this paper.

\section{References}

Baums, A.-B., Goldberg, V., and Bernhofer, C.: Upgrading the Coupled Vegetation Boundary Layer Model HIRVAC by New Soil Water and Interception Modules, Met. Z., 14(2), 211-218, 2005.

Bladon, K. D., Silins, U., Landhäusser, S. D., and Lieffers, V. J.: Differential transpiration by three boreal tree species in response to increased evaporative demand after variable retention harvesting, Agric. For. Meteorol., 138, 104-119, 2006.

Daamen, C. C. and McNaughton, K. G.: Modeling energy fluxes from sparse canopies and understorys, Agron. J., 92, 837-847, 2000

Daudet, F. A., Le Roux, X., Sinoquet, H., and Adam, A.: Wind speed and leaf boundary conductance variation within tree crown, Consequences on leaf-atmosphere coupling and tree functions, Agric. For. Meteorol., 97, 171-185, 1999.

Falge, E., Graber, W., Siegwolf, R., and Tenhunen, J. D.: A model of the gas exchange re-sponse of Picea abies to habitat conditions, Trees, 10, 277-287, 1996.

Falge, E., Ryel, R. J., Alsheimer, M., and Tenhunen, J. D.: Effects of stand structure and physiology on forest gas exchange: a simulation study for Norway spruce, Trees, 11, 436-448, 1997.

Falge, E., Tenhunen, J. D., Alsheimer, M., and Köstner, B.: Modelling age- and density-related gas exchange of Picea abiescanopies in the Fichtelgebirge, Germany, Ann. For. Sci., 57, 229243, 2000

Falge, E., Reth, S., Brüggemann, N., Butterbach-Bahl, K., Goldberg, V., Oltchev, A., Schaaf, S., Spindler, G., Stiller, B., Queck, R., Köstner, B., and Bernhofer, C.: Comparison of surface energy exchange models in VERTIKO, Ecol. Modeling, 188, 174216, 2005

Fischer, B., Goldberg, V., and Bernhofer, C.: Effect of a coupled soil water - plant gas exchange on forest energy fluxes: Simulations with the coupled vegetation - boundary layer model HIRVAC, Ecol. Modelling, 214, 75-82, 2008.

Goldberg, V. and Bernhofer, C.: Quantifying the coupling degree between land surface and the atmospheric boundary layer with the coupled vegetation-atmosphere model HIRVAC, Ann. Geophys., 19, 581-587, 2001, http://www.ann-geophys.net/19/581/2001/

Goldberg, V., Fischer, B., and Bernhofer, C.: Effect of a coupled soil water - plant gas exchange on forest energy balance: simulations with the coupled soil-vegetation-boundary layer model HIRVAC, Ann. Meteorol., 41, 54-57, 2005.

Herbst, M.: Stomatal behaviour in a beech canopy: an analysis of Bowen ratio measurements compared with porometer data, Plant,
Cell Environ., 18, 1010-1018, 1995.

Jacobs, C. M. J. and de Bruin, H. A. R.: The sensitivity of regional transpiration to land-surface characteristics: Significance of feedback, J. Climate, 5(7), 683-698, 1992.

Kelliher, F. M., Whitehead, D., McAneney, K. J., and Judd, M. J.: Partitioning evapotranspiration into tree and understorey components in two young Pinus radiata D. don stands, Agric. For. Meteorol., 50, 211-227, 1990.

Köstner, B. M. M., Schulze, E.-D., Kelliher, F. M., Hollinger, D. Y., Byers, J. N., Hunt, J. E., McSeveny, T. M., Meserth, R., and Weir, P. L.: Transpiration and canopy conductance in a pristine broadleaved forest of Nothofagus: an analysis of xylem sap flow and eddy correlation measurements, Oecologia, 91, 350-359, 1992.

Kumagai, T., Saitoh, T. M., Sato, Y., Morooka, T., Manfroi, O. J., Kuraji, K., and Suzuki, M.: Transpiration, canopy conductance and the decoupling coefficient of al lowland mixed dipterocarp forest in Sarawak, Borneo: dry spell effects, J. Hydrol., 287, 237-251, 2004.

Magnani, F., Leonardi, S., Tognetti, R., and Borghetti, M.: Modelling the surface conductance of a broad-leaf canopy: effects of partial decoupling from the atmosphere, Plant, Cell and Environ., 21, 867-879, 1998.

Martin, P.: The significance of radiative coupling between vegetation and the atmosphere, Agric. For. Meteorol., 49, 45-53, 1989.

Martin, T. A., Brown, K. J., Kučera, J., Meinzer, F. C., Sprugel, D. G., and Hinckley, T. M.: Control of transpiration in a 220-yearold Abies amabilis forest, Forest Ecology and Management, 152, 211-224, 2001.

McNaughton, K. G. and Jarvis, P. G.: Predicting effects of vegetation changes on transpiration and evaporation, in: Water Deficit and Plant Growth, edited by: Koslowski, T. T., Academic Press, New York, 7, 1-47, 1983.

McNaughton, K. G. and Jarvis, P. G.: Effects of spatial scale on stomatal control of transpiration, Agric. For. Meteorol., 54, 279301, 1991.

Meinzer, F. C. and Grantz, D. A.: Stomatal control of transpiration from a developing sugarcane canopy, Plant, Cell Environ., 12, 635-642, 1989.

Meinzer, F. C., Goldstein, G., Holbrook, N. M., Jackson, P., and Cavelier, J.: Stomatal and environmental control of transpiration in a lowland tropical forest tree, Plant, Cell Environ., 16, 429436, 1993.

Meinzer, F. C., Andrade, J. L., Goldstein, G., Holbrook, N. M., Cavelier, J., and Jackson, P.: Control of transpiration from the upper canopy of a tropical forest: the role of stomatal, boundary layer and hydraulic architecture components, Plant, Cell Environ., 20, 1242-1252, 1997.

Mielke, M. S., Oliva, M. A., de Barros, N. F., Penchel, R. M., Martinez, C. A., and de Almeida, A. C.: Stomatal control of transpiration in the canopy of a clonal Eucalyptus grandis plantation, Trees, 13, 152-160, 1999.

Mix, W., Goldberg, V., and Bernhardt, K.-H.: Numerical experiments with different approaches under large-area forest canopy conditions, Met. Z., 3(4), 187-192, 1994.

Morris, J., Mann, L., and Collopy, J.: Transpiration and canopy conductance in a eucalypt plantation using shallow saline groundwater, Tree Physiology, 18, 547-555, 1998.

Motzer, T., Munz, N., Küppers, M., Schmitt, D., and Anhuf, D.: Stomatal conductance, transpiration and sap flow of tropical 
montane rain forest trees in the southern Ecuadorian Andes, Tree Physiology, 25, 1283-1293, 2005.

Pereira, A. R.: The Priestley-Taylor parameter and the decoupling factor for estimating reference evapotranspiration, Agric. For. Meteorol., 125, 305-313, 2004.

Pinty, J.-P., Mascart, P., Bechtold, P., and Rosset, R.: An application of the vegetation-atmosphere concept to the HAPEX-MOBILHY experiment, Agric. For. Meteorol., 61, 253-279, 1992.

Shaw, R. H. and Schumann, U.: Large-eddy simulation of turbulent flow above and within a forest, Bound.-Lay. Meteorol., 61, 4764, 1992.

Smith, D. M. and Jarvis, P. G.: Physiological and environmental control of transpiration by trees in windbreaks, Forest Ecology and Management, 105, 159-173, 1998.

Smith, D. M., Jarvis, P. G., and Odongo, J. C. W.: Management of windbreaks in the Sahel: the strategic implications of tree water use, Agroforestry Systems, 40, 83-96, 1998.

Steppeler, J., Doms, G., Schättler, U., Bitzer, H. W., Gassmann, A., Damrath, U., and Gregoric, G.: Meso-gamma scale forecasts using the non hydrostatic model LM. Meteorol, Atmos. Phys., 82, 75-96, 2003.
Tausend, P. C., Meinzer, F. C., and Goldstein, G.: Control of transpiration in three coffee cultivars: the role of hydraulic and crown architecture, Trees, 14, 181-190, 2000.

Watanabe, T.: Large Eddy Simulation of coherent turbulence structures associated with scalar ramps over plant canopies, Bound.Lay. Meteorol., 112, 307-341, 2004.

White, D. A., Beadle, C. L., and Worledge, D.: Control of transpiration in an irrigated Eucalyptus globulus Labill. Plantation, Plant, Cell Environ., 23, 123-134, 2000.

Wullschleger, S. D., Wilson, K. B., and Hanson, P. J.: Environmental control of whole-plant transpiration, canopy conductance and estimates of the decoupling coefficient for large red maple trees, Agric. For. Meteorol., 104, 157-168, 2000.

Wullschleger, S. D., Gunderson, C. A., Hanson, P. J., Wilson, K. B., and Norby, R. J.: Sensitivity and canopy conductance to elevated $\mathrm{CO}_{2}$ concentration - interacting variables and perspective of scale, New Phytologist, 153, 485-496, 2002. 